\title{
Jist 141965
}

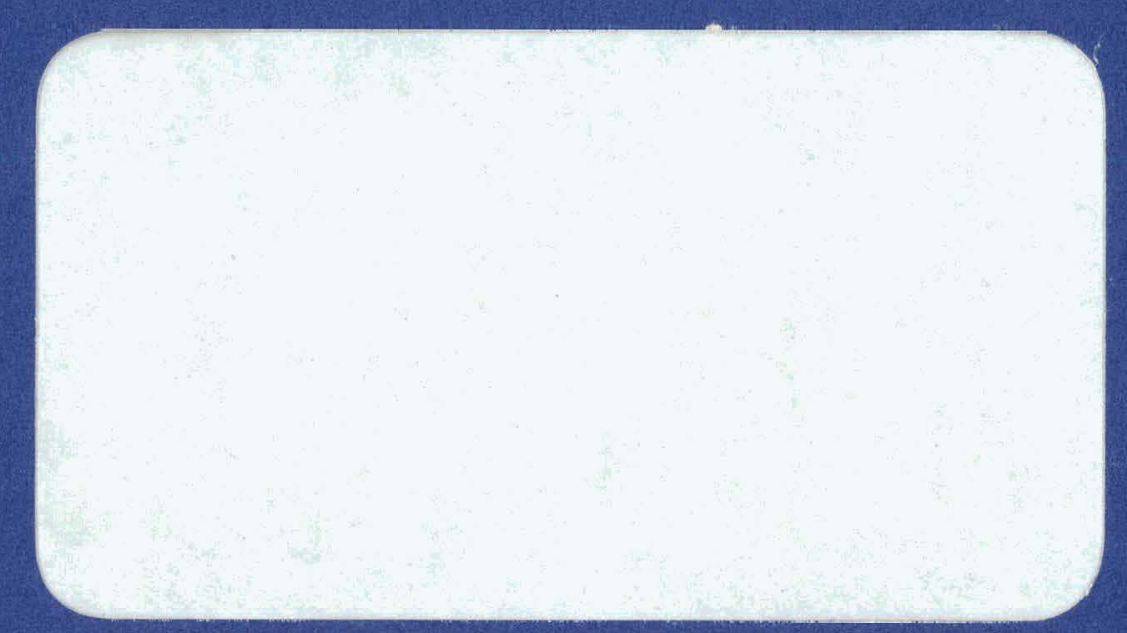

PATENI CLEARANGE OBIALNED. RELEASE TO

THE PUBLIC IS APPROVEA PROCEDURES

WUE ON DULE HA THE REGEIVING SECTIOA:

Westinghouse Atomic Power Division

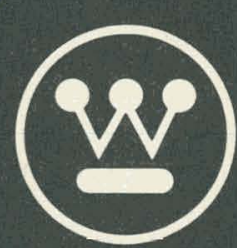




\section{DISCLAIMER}

This report was prepared as an account of work sponsored by an agency of the United States Government. Neither the United States Government nor any agency Thereof, nor any of their employees, makes any warranty, express or implied, or assumes any legal liability or responsibility for the accuracy, completeness, or usefulness of any information, apparatus, product, or process disclosed, or represents that its use would not infringe privately owned rights. Reference herein to any specific commercial product, process, or service by trade name, trademark, manufacturer, or otherwise does not necessarily constitute or imply its endorsement, recommendation, or favoring by the United States Government or any agency thereof. The views and opinions of authors expressed herein do not necessarily state or reflect those of the United States Government or any agency thereof. 


\section{DISCLAIMER}

Portions of this document may be illegible in electronic image products. Images are produced from the best available original document. 
WCAP-3269-10

UC-80 React or Technology

Special Distribution

STEAM GENERATOR WATER LEVELL CONTROL

December 1964

Amir N. Nahavandi and Abram Batenburg Plant Development

Prepared for the U. S. Atomic Energy Commission Under New York Operations Office. Contract AT(30-1)-3269 (Sub-task IRD-50I)

\author{
WESTINGHOUSE ELECTRIC CORPORATION \\ Atomic Power Division \\ P. O. Box 355 \\ Pittsburgh 30 , Pennsylvania
}


Thle repert wa propered al an cooount of Government epongored work.

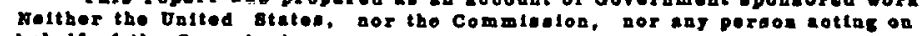
Welther the United stales,
belelf of the Commiegton:

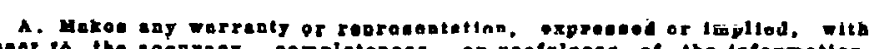

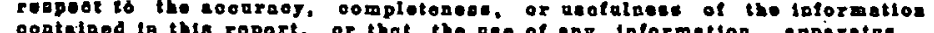
conteinod ta this roport, or that tho deo of ang folormation, apparated. mothod, or prooose dicoloood in
rickte; or

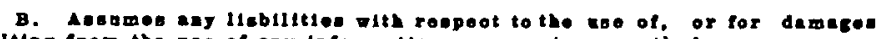
rearlting trom the ean of ay laformation, apparates, mothod, or prooes disoloced in thite report.

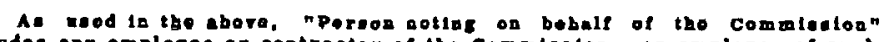

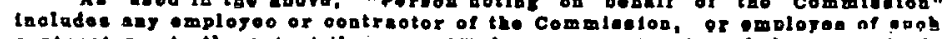

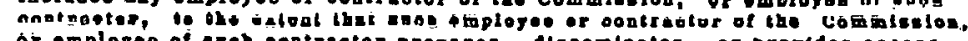
of omplogeo of ceos oontraotor properes. dianomlastos, or providen nocoges to, an laformation parenat to dle omplojment or oontreet alth the com-

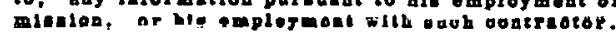


USAEC, New York Operations Office, 376 Hudson St., New York 14; N.Y. Director, Reactor Development Division

USAEC, Resident Engineer, Westinghouse Atomic Power Division

USAEC, Division of Reactor Development and Technology, Washington 25, D. C. Attn: W. R. Voigt

USAEC, Division of Technical Information, P. 0. Box 62; Oak Ridge, Tennessee

USAEC, Assistant General Counsel for Patents, Gernantown, Maryland Attn: R. A. Anderson

General Electric Atomic Power Equipment Dept., 2151 South First St.,

San Jose, Callfornia, Attn: Aileen Thompson

The Babcock \& Wilcox Co., Atomic Energy Division, 1201 Kemper St.,

P. 0. Box 1260, Lynchburg, Virginia, Attn: J. W. Landis

Allis-Chalmers Manufacturing Co., Nuclear Power Dept. - Greendale,

P. O. Box 512, Milwaukee 1, Wisconsin, Attn: C. B. Graham

Combustion Engineering, Inc., Nuclear Division, Windsor, Connecticut,

Attn: A. F. Miller

Hanford Atomic Products Operations, General Electric Co., Richland, Washington, Attn: W. S. Dowis

Argonne National Laboratory, P. O. Box 299, Lemont, Illinois, Attn: A. V. Crewe

Yankee Atomic Electric Co., 441 Stuart St., Boston 16, Massachusetts,

Attn: R. J. Coe

Yankee Atomic Electric Co., 441 Stuart St., Boston 16, Massachusetts,

Attn: D. E. Vandenburgh

Los Angeles Dept. of Water \& Power, 207 South Broadway, P. 0. Box 3669, 1

Terminal Annex, Los Angeles 54, Californị, Attn: S. B. Nelson

Connecticut Yankee Atomic Power Co., P. O. Box 2010, Hartford 1,

Connecticut, Attn: S. R. Knapp

Sinithern California Edison Co., P. O. Box 351, Los Angelee 53;

California, Attn: J. F. Davenport

Southern California Edison Co., P. O. Box 351, Los Angeles 53,

California, Attn: J. B. Henderson

San Diego Gas \& Electric Co., P. O. Box 1831, San Diego 12, California . 1 Attn: C. M. Laffoon 
Iist of Figures ....................... . ili

Nomenclature ..................... . . . vi vi

Abstract .......................... . $x$

Introduction ......................... 1

Recirculation Loop Space-Dependent Digital Model 。. . . . . 5

Steam Drum Analog Model ................... 13

Water Ievel Controller Analog Model . . . . . . . . 13

Feedwater Line Analog Model . . . . . . . . . . 。 16

Steam Main to Turbine Analog Model . . . . . . . . . . 16

Presentation of Results . . . . . . . . . . . . .. 17

Acknowledgement . . . . . . . . . . . . . . . . 29

References ..................... 30

Appendix I - Details of Recirculation Loop Space-

Dependent Digital Model ........... 31

Appendix 2 - Details of Steam Drum Analog Model . . . . 36

Appendix 3 - Details of Feedwater Line Analog Model o . . . 37

Appendix 4 - Details of Steam Main to Turbine Analog

Table I $\quad$ - Feedwater Valve Positioner Transfer

Function and Characteristics . . . . . . . 4.1

Table II - Steam Generator Parameters . . . . . . . 41

Table III - Values of Constants $C_{1}$ to $C_{12}$. . ! . . . . 41 
Fig. 2-a Change in. Water Level for $10 \%$ Step Increase in Feedwater Mass Flow Rate

Fig. 2-b Frequency Response of the Water Level Transfer Function for a.10\% Step Increase in Feedwater Mass Flow Rate

Fig. 3-a Change in Steam.Discharge for a $10 \%$ Step. Increase in. Feedwater Mass Flow Rate

Fig. 3-b Frequency Response of the Steam Discharge Transfer Function for a $10 \%$ Step Increase in Feedwater Mass Flow Rate

Fig. 4-a Change in Water Level for a $10 \%$ step Increase in System Thermal Power Input

Fig. 4-b Frequency Response of the Water Level Transfer Function for a 10\% Step Increase in System Thermal Power Input

Fig. 5-a. Thange in Steam Discharge for a $10 \%$ step Increase in System Thermal Power Input

F1g: 5-b Frequency Response of the Steam Discharge Transfer Function for a $10 \%$ Step Increase in System Thermal Power Input 
Fig. 6-a Change in Water Level for a 50 psi Step Decrease

in System Pressure

Fig. 6-b Frequency Response of the Water Level Transfer

Function for 3. 50 psi Step Decrease in System

Pressure

Fig. 7-a Change in Steam Discharge for a 50 psi Step. Decrease in System .Pressure

Fig. 7-b. Frequency Response of the Steam Discharge Transfer

Function for a 50 psi Step Decrease in. System

Pressure

Fig. 8-a Initial Steam Generator Level Control System

Fig. 8-b F'inal Steam Generator Level Control System

Fig. 10-a Stability Limits as a Function of $\mathrm{K}_{1}$ and $\mathrm{K}_{2}$ for $\tau_{2}=20$ sec., $\tau=0$ sec。 and
a) $\tau_{1}=50 \mathrm{sec}$.
b) $r_{1}=25 \mathrm{sec}$.
c) $\tau_{1}=12.5$ sec:

Fig. 10-b Stability and Response Limits as a Function of $K_{1}$ and $K_{2}$ for $\tau_{1}=50$ sec, $\tau_{2}=20$ occ and $\tau-0$ sec.

Fig. Il Step Response of Steam Cenerator Water Level Change for a $10 \%$ Step Increase in Turbine Governor Valve Area for Different Values of $\mathrm{K}_{1}$ 
Fig. 12 Step Response of Steam Generator Water Leve1 Change for a $10 \%$ Step Increase in Turbine Governor Valve Area for Different Values of $\mathrm{K}_{2}$

Fig. 13 Step Response of Steam Generator Water Level Change for a $10 \%$ step Increase in Turbine Governor Valve Area for Different Values of $\tau_{1}$

Fig. 14 Step Response of Steam Generator Water Level Change for a $10 \%$ step Increase in. Turbine Governor Valve Area for Different Values of $T$

Fig. 15 Response of the Feedwater Loop for a Unit Step Change in. Set Point

Fig. 16 Response of the Water Level Control System for a Step Change of 2.25 Inches in Set Point

Fig. 17 Step Response of Steam Generator Six Most Important 28 Variables for a 10\% Step Increase in Turbine Governor Valve Area for Opilmum Controller Seltings

Fig. 18 Special Analog Simulation Symbols 


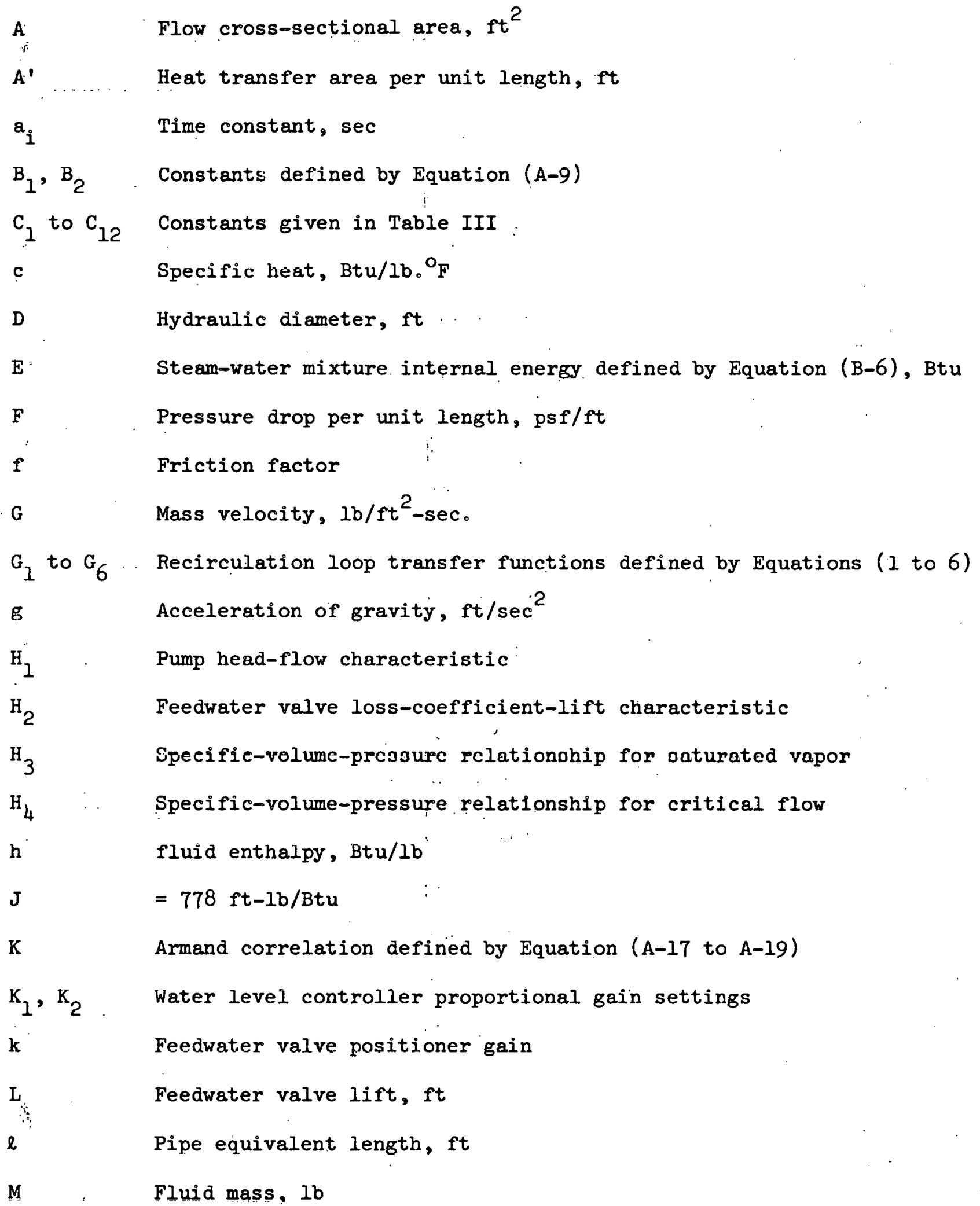


Fluid mass flow rate, $1 \mathrm{~b} / \mathrm{sec}$

Reynolds number

Thermal power input into the steam generator per unit length, Btu/sec-ft

Steam generator pressure, psf

Feedwater pump discharge pressure, psf

Heat transfer rate per un ft volume, Btu/ ft $\mathrm{ft}^{3}-\mathrm{sec}$

Conduit roughness

Laplace transform variable

Temperature, ${ }^{\circ} \mathrm{F}$

Time, sec

Overall heat transfer coefficient, $B t u / f t^{2}-\sec -{ }^{\circ} F$

Fluid velocity, ft/sec

Liquid velocity at the inlet to the downcomer, $\mathrm{ft} / \mathrm{sec}$

Steam drum volume, $\mathrm{ft}^{3}$.

Specific volume, $\mathrm{ft}^{3} / \mathrm{lb}$

$\mathbf{x} \quad$ Steam quality

y. Water level, ft

\& Void fraction

$r$ Slip ratio

$\Delta p \quad$ Pressure drop, psf

$\Delta r \quad$ Film temperature drop, ${ }^{\circ} \mathrm{F}$

$\Delta t \quad$ Time increment, sec

$\Delta z \quad$ Length increment, ft

$\Delta z^{\prime} \quad$ Equivalent length increment; ft

$\zeta$ Feedwater valve positioner damping factor 
$\theta$

$\rho$

$\tau$

$\tau_{1}, \tau_{2}$

$\tau_{3}$

$\omega_{n}$

SUBSCRIPTS

c

er

a

de

I

g

h

180

j

je

ji

m

n

0

r1
Angle between the fluld velocity vector and $-g$ (where $g$.is the acceleration of gravity vector)

Flutd density, $1 \mathrm{~b} / \mathrm{ft}^{3}$

Water level slgnal filter time constant, sec.

Water level controller reset constants, sec

Valve motor time constant, sec

Feedwater valve positioner natural frequency, sec $^{-1}$

Feedwater Iine

Critical flow

Steam discharge out of the recirculation loop

Downcomer

Saturated Iiquid

Sàturated vapor

Hèating zone

Isothermal

An arbitrary element in the recirculation 10op

Feedwater into or steam discharge out of an arbitrary element in the recirculation loop

Inlet to an arbitrary element in the recirculation loop

Governor valve opening

Governor valve inlet

Steady state value

Riser 
8

8p

t

th

tp

$\sum^{w}$

SUPERSCRIPT
Steam main to turbine

Single phase

Steam generator U-tube

U-tube to heating zone

Two-phase

subcooled region

Summation over all the contractions around the recirculation loop

Summation over all the expansions around the recirculation loop

Variation from steady state

Average 
A combined digital-analog mathematical model for the dynamic analysis of vertical U-tube natural circulation steam generators is presented: The application of this model to the optimal design of a water level controller for a steam generating unit is demonstrated. It is shown that a control system consisting of standard proportional and reset controls on water level deviation from a desired set point and the duifference between the steam and feedwater mass flow rates can be successfully employed for the control of water level in such a.plant. The optimum values, as well as the range of the controller parameter settings for which the steam generator exhibits a desired stable response, are determined. 
INTRODUCTION

The control of water level and feedwater is extremely important to the operation of conventional steam generating and boliing water reactor plants. Large water level variation can affect system power and hydrodynamic stability. Transient changes in feedwater flow not only affect the plant power output but may also create a thermal shock problem. In order to minimize these adverse effects, it is desirable to hold the water level as close to a predetermined set point as possible, even during large fluctuations in steaming rate, without large changes in feedwater flow rate (I).

Earlier water level control studies used "lumped-parameter" representation of flow behavior in various system flow segments. The mathematical. model was then simulated on a real-time conventional analog computer for the optimization of the water level controller parameters (2). In a lumped-parameter model, restrictive assumptions pertaining to the spatial distribution of the dependent variables within each segment must be made; thereby reducing the accuracy of the solution. Rigorous water level control studies must include the simultaneous solution of the space-dependent time-dependent conservation equations of mass, momentum and energy for the coolant flow through the steam plant. Dynamic models of this type are extremely involved and their solution requires fast repetitive analog and/or high speed digital computers. Fast repetitive analog computers, with their capabilities for memory storage, can be made to operate with two independent variables (length along the flow path and time). Digital computers can be programed to employ powerful direct-search techniques for an automatic optimization of controller parameter settings. Controller optimization studies employing fast repetitive analog and/or high speed digital computers are in their early stages of development and their results are not yet available. In the meantime, a combined aigital-analog water level control study, which is a compromise between analytical rigor and computational cost, has been initiated by the authors. This model, on one hand does not suffer from the restrictive assumptions of the earlier lumped-parameter models. On the other hand, its less elaborate structure, in comparison with the spacedependent time-dependent models, provides an economical means for conducting systems control studies. In essence, this combined digital-analog water level controller atudy consists of two parts:

$$
-1-
$$

Underlined numbers in parentheses designate references at the end of this study. 
The first part is a digital computer program simulating the dynamic behavior of the steam plant recirculation loop (Fig. I) with length along the flow path and time as system independent variables. It must be realized that spatial effects in the recirculation loop (consisting of the downcomer, heating zone, riser and steam separator) are of great importance to the system stability and dynamic performance. Hence, a lumped-parameter representation cannot accurately describe the recirculation loop flow behavior. The second part is an analog simulator for controller parameter optimization studies. The analog simulator consists of five distinct blocks:. 1) feedwater line; 2) steam drum; 3) steam main to turbine; 4) water level controller; and 5) recirculation loop model.

Employing the recirculation loop digital simulation program, the water level and steam discharge rate transient response for step changes in feedwater flow rate, pressure and thermal power input were first determined. Using analog and digital techniques, six linear transfer functions were then derived by a time-to-frequency domain transformation. These transfer functions were employed as the steam generator recirculation loop model in the analog simulator. In contrast with the recirculation loop, spatial effects are less significant in the development of the other four analog simulator blocks. Hence, analytical expressions using lumped-parameter representation were derived and employed for the simulation of the feedwater line, steam drum, steam main to turbine and level controller models.

The main objectives of this study are:

1) To present a combined digital-analog mathematical model. for the dynamic analysis of vertical U-tibe natural circulation steam generators for closed-cycle pressurized water nuclear power stations.

2). To design an optimal water level controller for the steam plant to fulfill the following basic requirements, common to most control schemes.

a) The controller must malntain the water level at the required position, in the presence of load variations. 


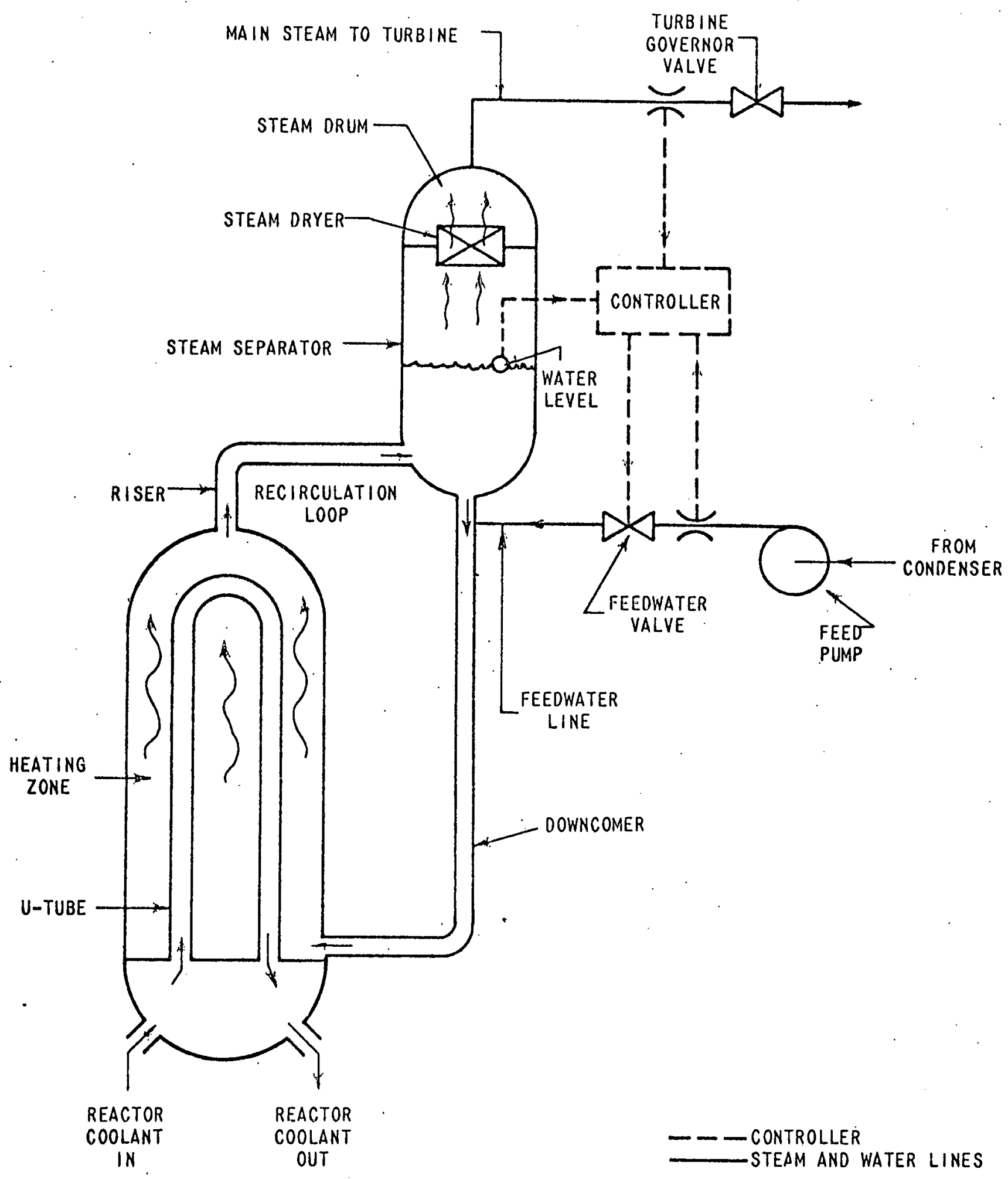

SCHEMATIC DIAGRAM OF VERTICAL U-TUBE STEAM GENERATOR 
b) The response time, i.e., the time required for the water level deviation to approach zero, should be reasonably small.

c) The overall plant and controller system, as well as all individual loops, must be inherently stable.

3) To reduce the controller cost by employing a relatively low-speed feedwater control valve and standard equipment in the controller design.

The steam generating units transfer heat from the primary (reactor) coolant system to the secondary system, where steam is produced to drive a turbinegenerator set. A typical steam generator is shown schematically in Fig. 1. These units consist essentially of two-regions: the recirculation loop, and the steam drum. The recirculation loop includes a heating zone, riser, steam separator and a downcomer. The steam-water mixture generated in the heating zone flows upward through the riser to steam separator. The nearly. dry steam leaves the recirculation $100 p$ and passes into the steam drum, where any remaining entrained moisture is extracted by moisture separators before the steam enters the turbine. The saturated water is returned to the top of the downcomer, where it mixes with cold feedwater from steam generator feed pumps. The subcooled mixture then flows downward to enter the heating zone. The necessary driving head is provided by the difference in density between the water in the downcomer and the steam-water mixture in the heating zone and riser. 


\section{RECIRCULATION LOOP SPACE-DEPENDENT DIGITAL MODEL}

The mathematical model for the recirculation loop is developed ( $\underline{3}$ ) under several assumptions. The system pressure, feedwater flow rate and thermal power input from the reactor coolant system are assumed to remain constant during the dynamic calculations. Variations of these parameters, however, are included in the analog simulator: by employing transfer functions developed by introducing initial step changes in pressure, feedwater flow and thermal power input. The spatial pressure variation throughout the recirculation loop is very small in comparison with the system operating pressure. Hence, the spatial and time variation of specific volume of subcooled liquid is taken as equal to that of the saturated liquid.

The coolant velocity and thermodynamic properties, and the U-tube metal temperature are assumed to be functions of length along the flow path and time only. The transverse variation of the foregoing variables are not considered. A onedimensional-space approach is believed to reveal the most important characteristics of the recirculation loop.

The fundamental equations and details of the digital computer solution for the recirculation. loop are presented in Appendix 1. Starting from a sei cf steady state values for the main dependent variables, the digital program is employed to determine the nonlinear time behavior of the water level at the top of the downcomer and the steam wischarge mass flow rate into the steam generator, feedwater flow rate and pressure. The tabulated time data (plotted in Figs. 2-a to 7-a) are then used to determine six transfer functions which describe the uncontrolled behavior of a linearized recirculation loop model. The following digital and analog approaches are employed for this purpose:

By means of a time-to-frequency domain transformation program, a tabular frequency response (plotted in Figs. 2-b to $7-b$ ) is obtained from the time response. From this. Bode plot or analog computer study, a closed form transfer function is then. estimated. Using a digital optimization program or analog 


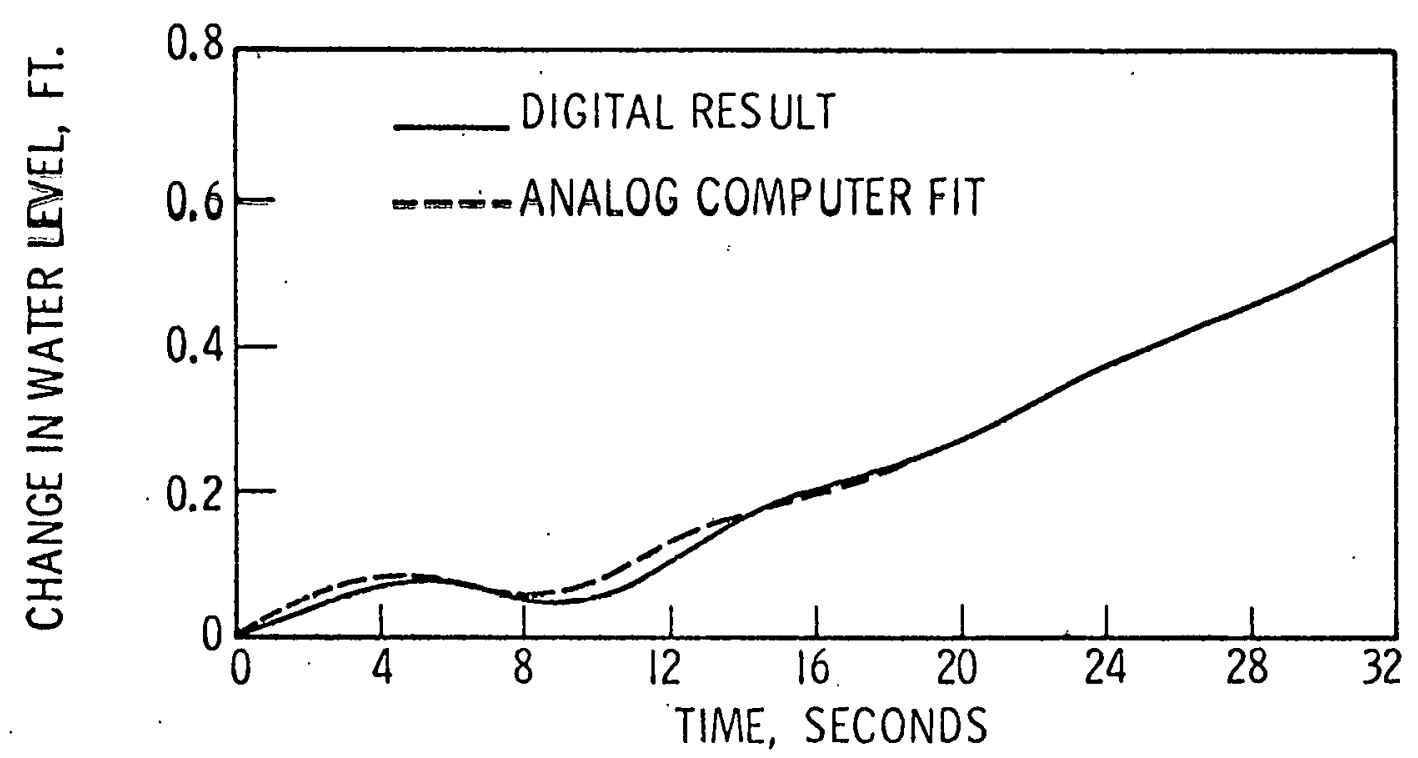

CHANGE IN WATER LEVEL FOR 10\% STEP INCREASE IN FEEDWATER MASS FLOW RATE

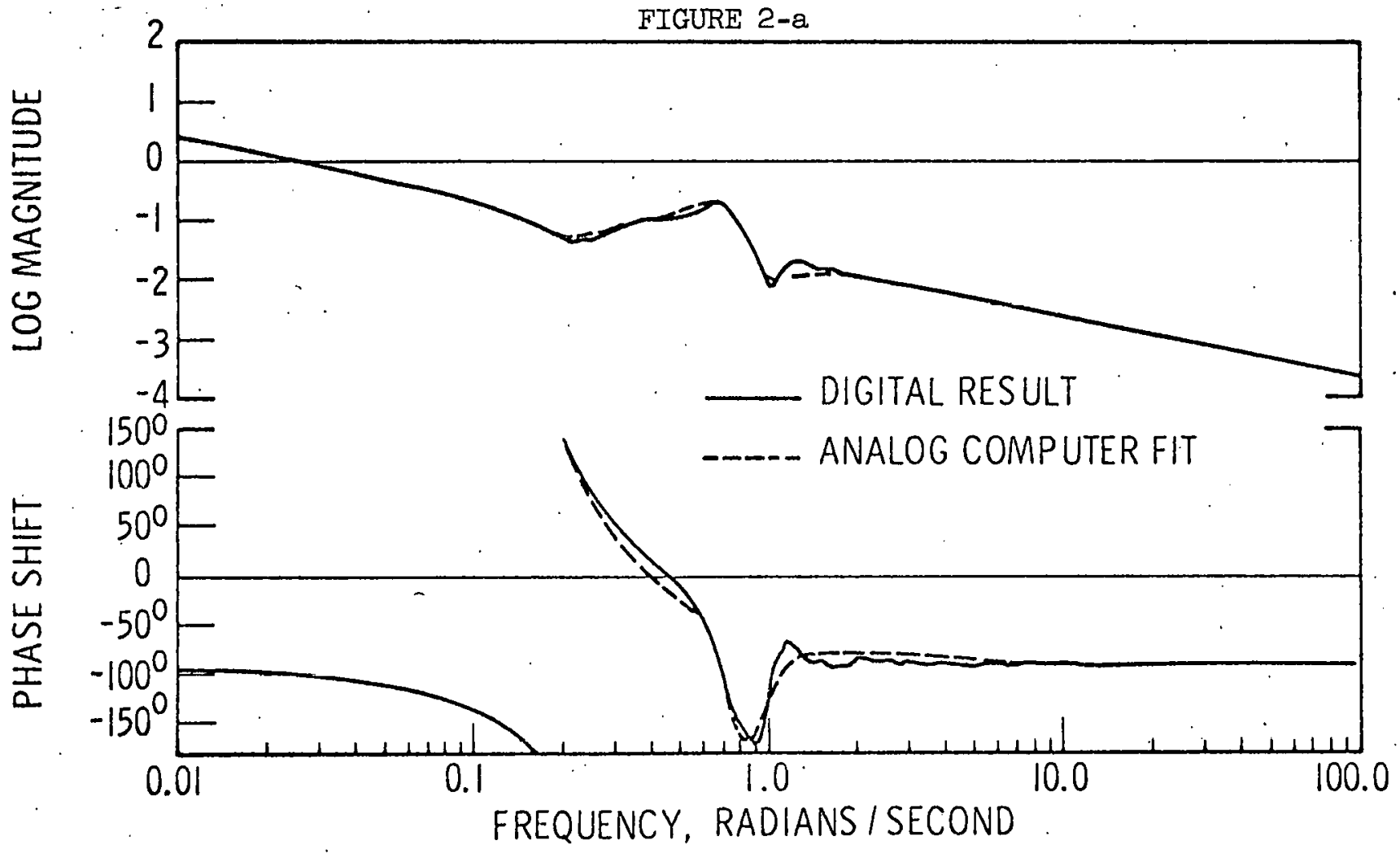

FREQUENCY RESPONSE OF THE WATER LEVEL TRANSFER FUNCTION FOR A $10 \%$ STEP INCREASE IN FEEDWATER MASS FLOW RATE 


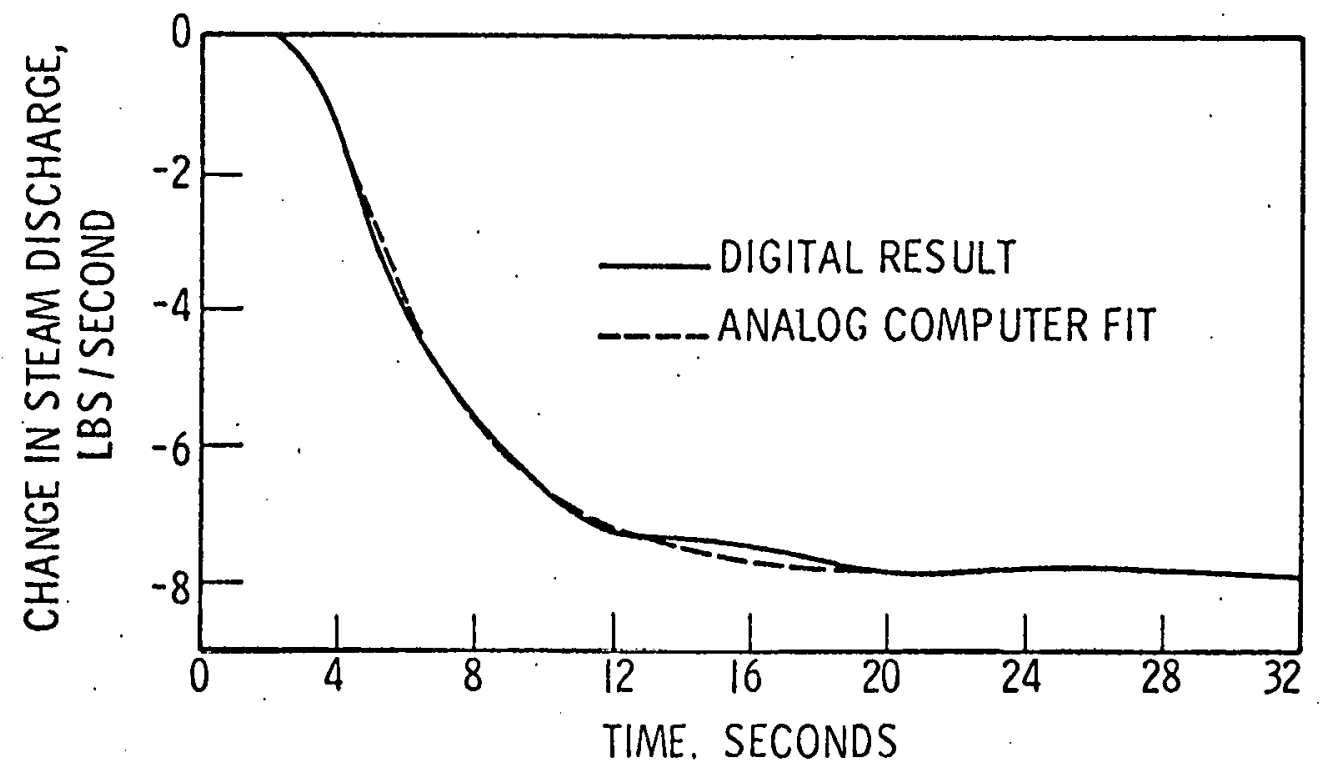

CHANGE IN STEAM DISCHARGE FOR A 10\% STEP INCREASE IN FEEDWATER MASS FLOW RATE

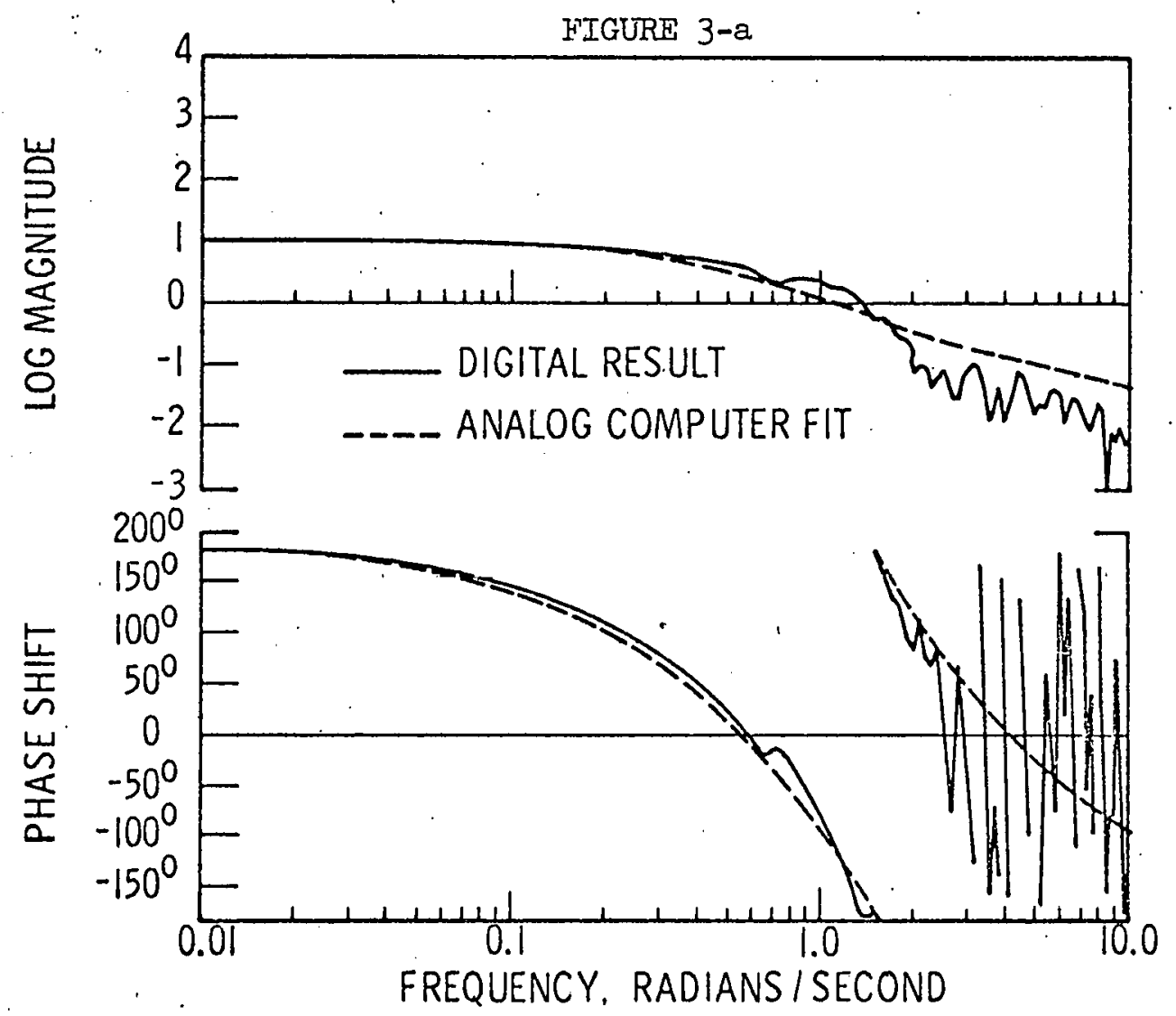

FREQUENCY RESPONSE OF THE STEAM DISCHARGE TRANSFER FUNCTION FOR A 10\% STEP INCREASE IN FEEDWATER MASS FLOW RATE 


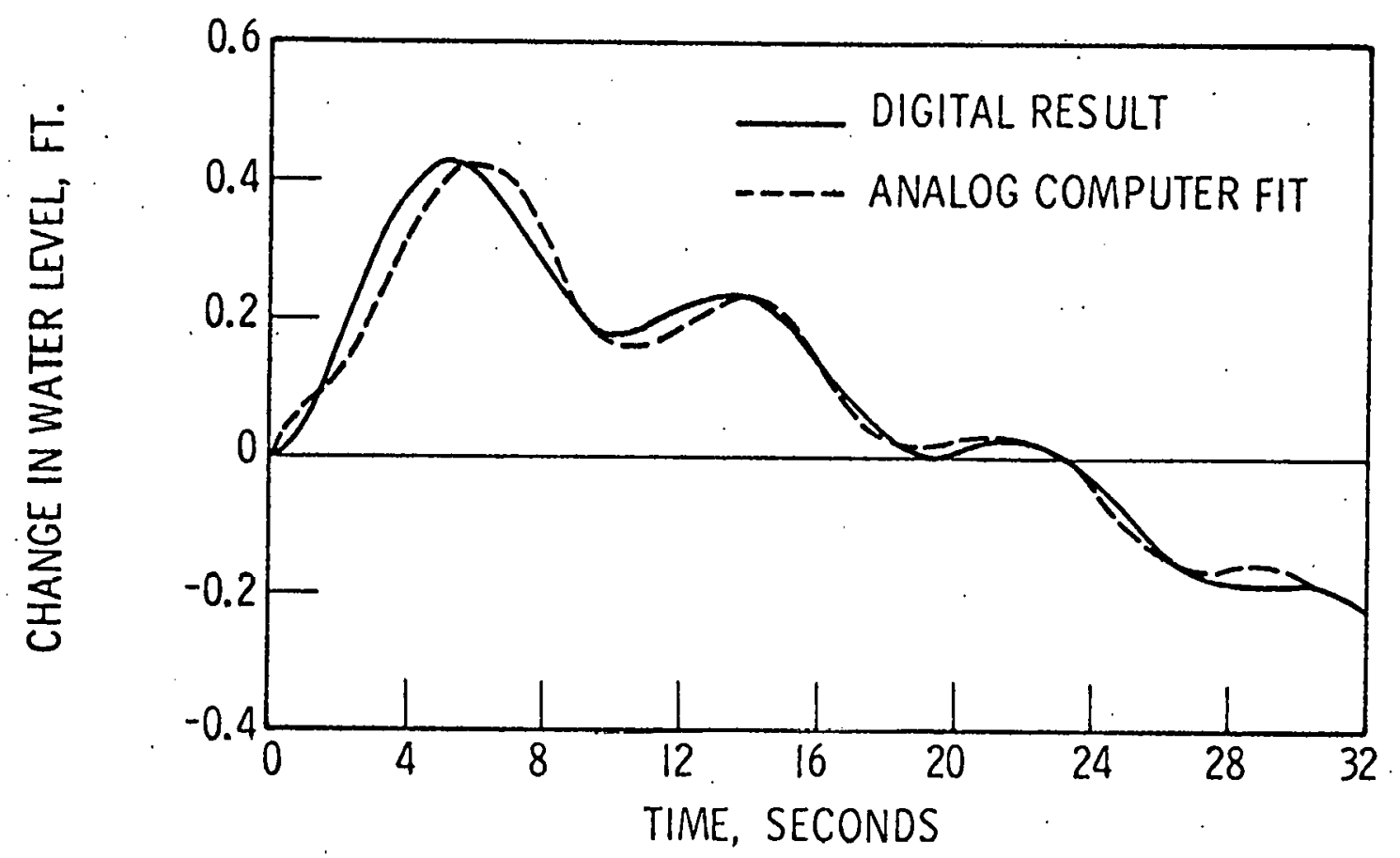

CHANGE IN WATER LEVEL FOR A 10\% STEP INCREASE IN SYSTEM THERMAL POWER INPUT FIGURE 4-a

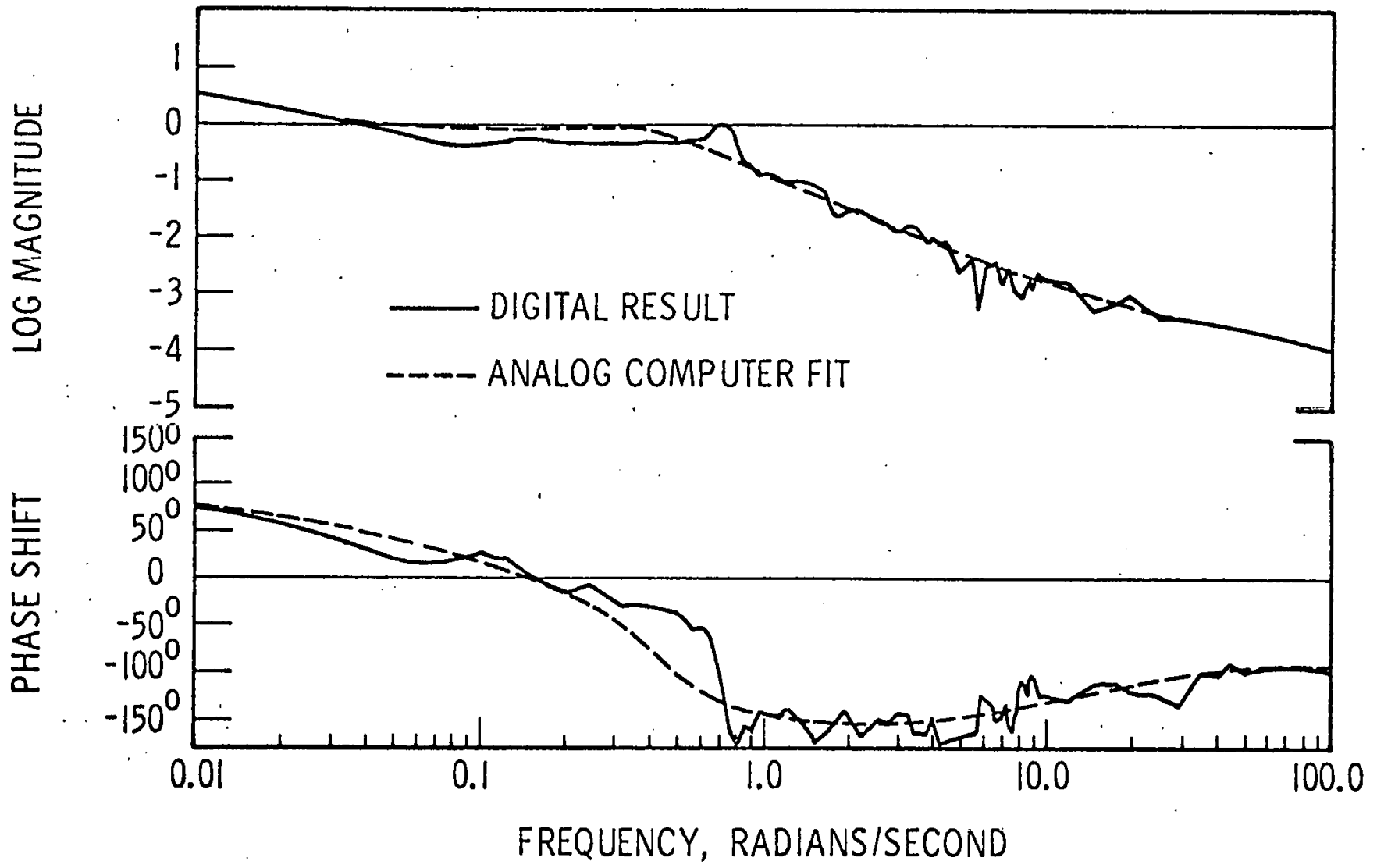

FREQUENCY RESPONSE OF THE WATER LEVEL TRANSFER FUNCTION FOR A 10\% STEP INCREASE IN SYSTEM THERMAL POWER INPUT 


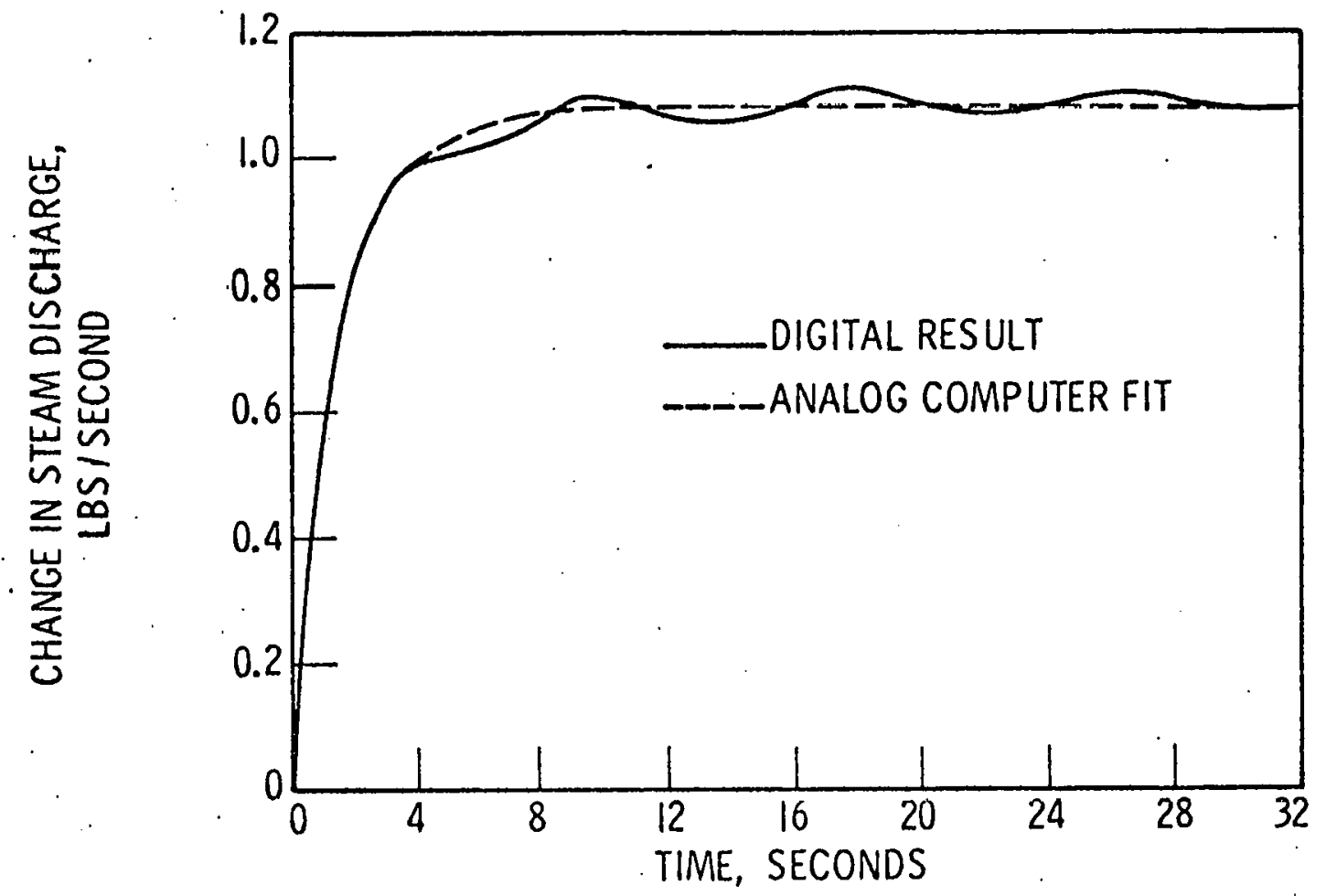

CHANGE IN STEAM DISCHARGE FOR A 10\% STEP INCREASE IN SYSTEM THERMAL POWER INPUT

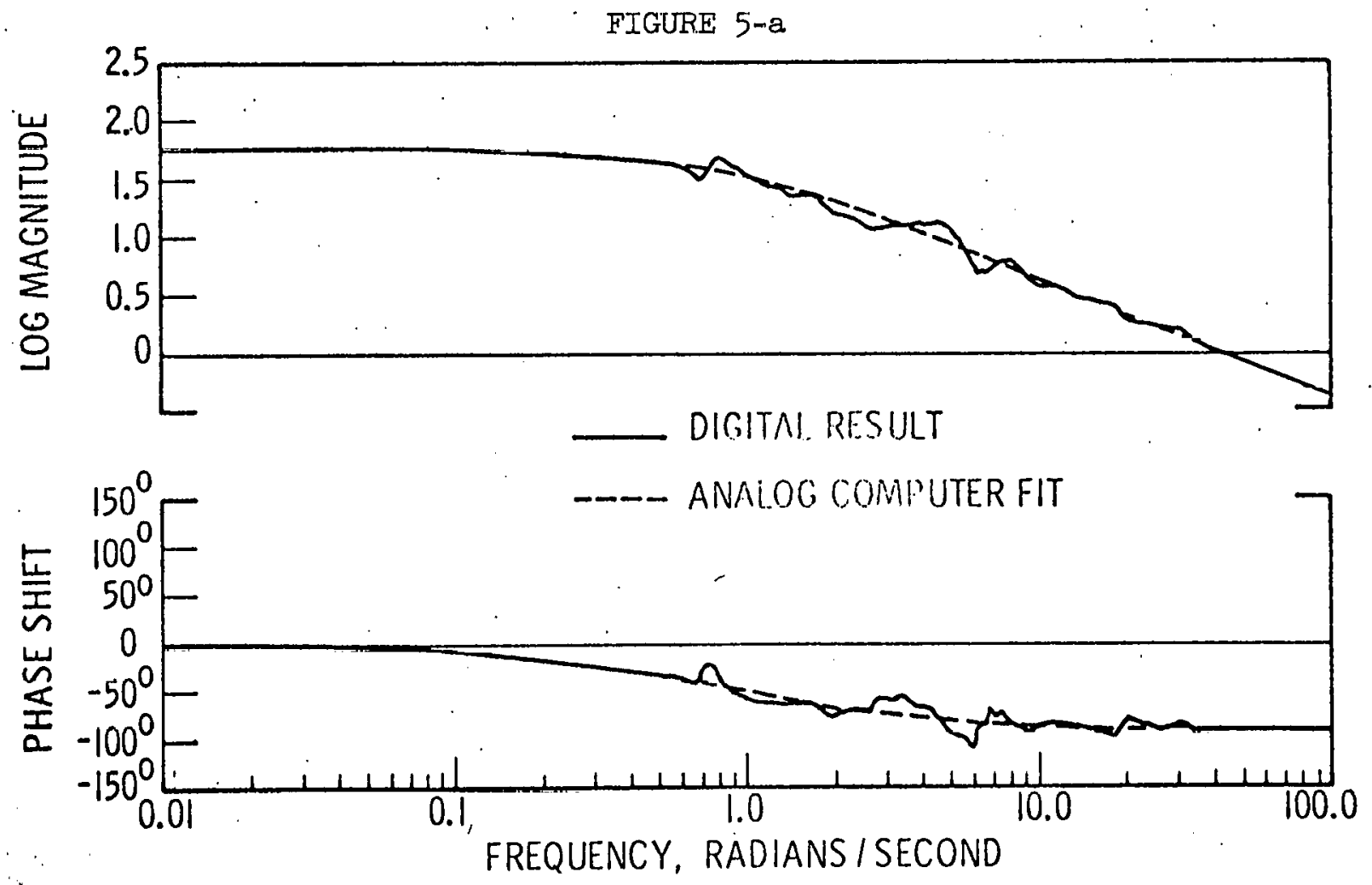

FREQUENCY RESPONSE OF THE STEAM DISCHARGE TRANSFER FUNCTION FOR A 10\% STEP INCREASE IN SYSTEM THERMAL POWER INPUT 


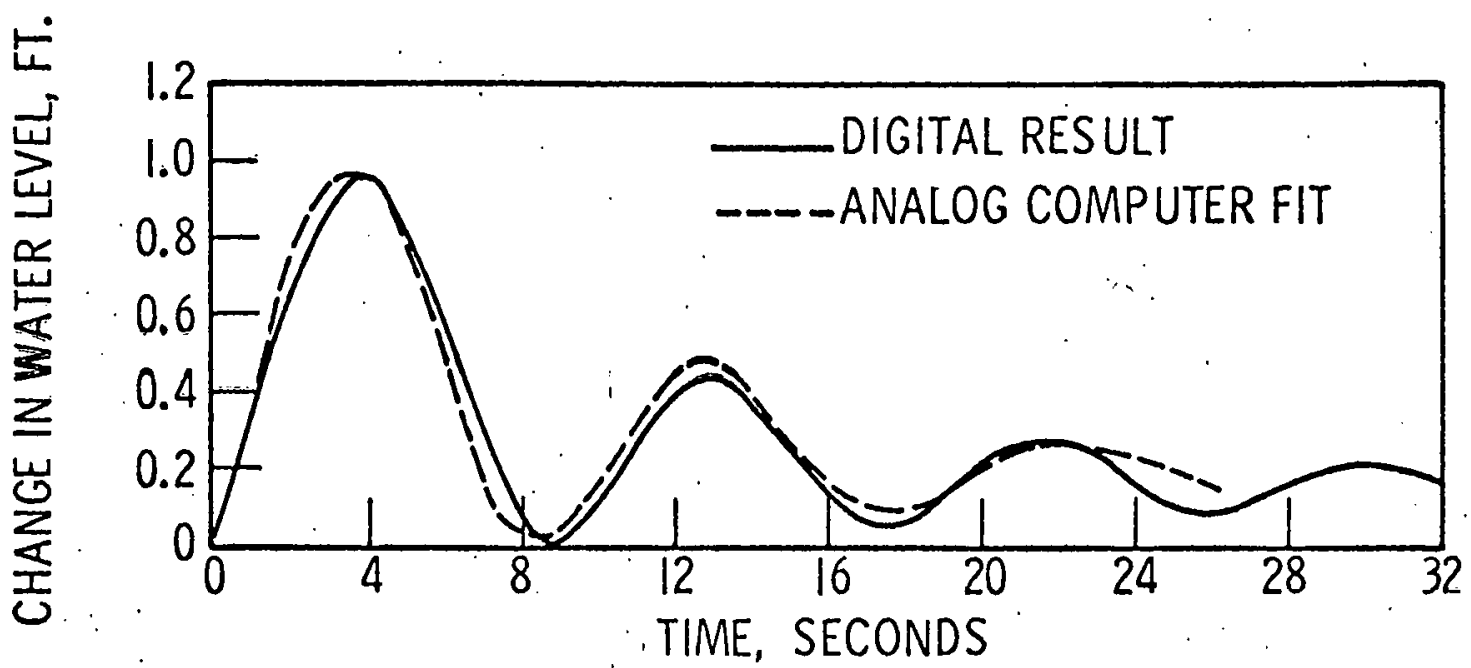

CHANGE IN WATER 'LEVEL FOR A 50 PSI STEP DECREASE IN SYSTEM PRESSURE

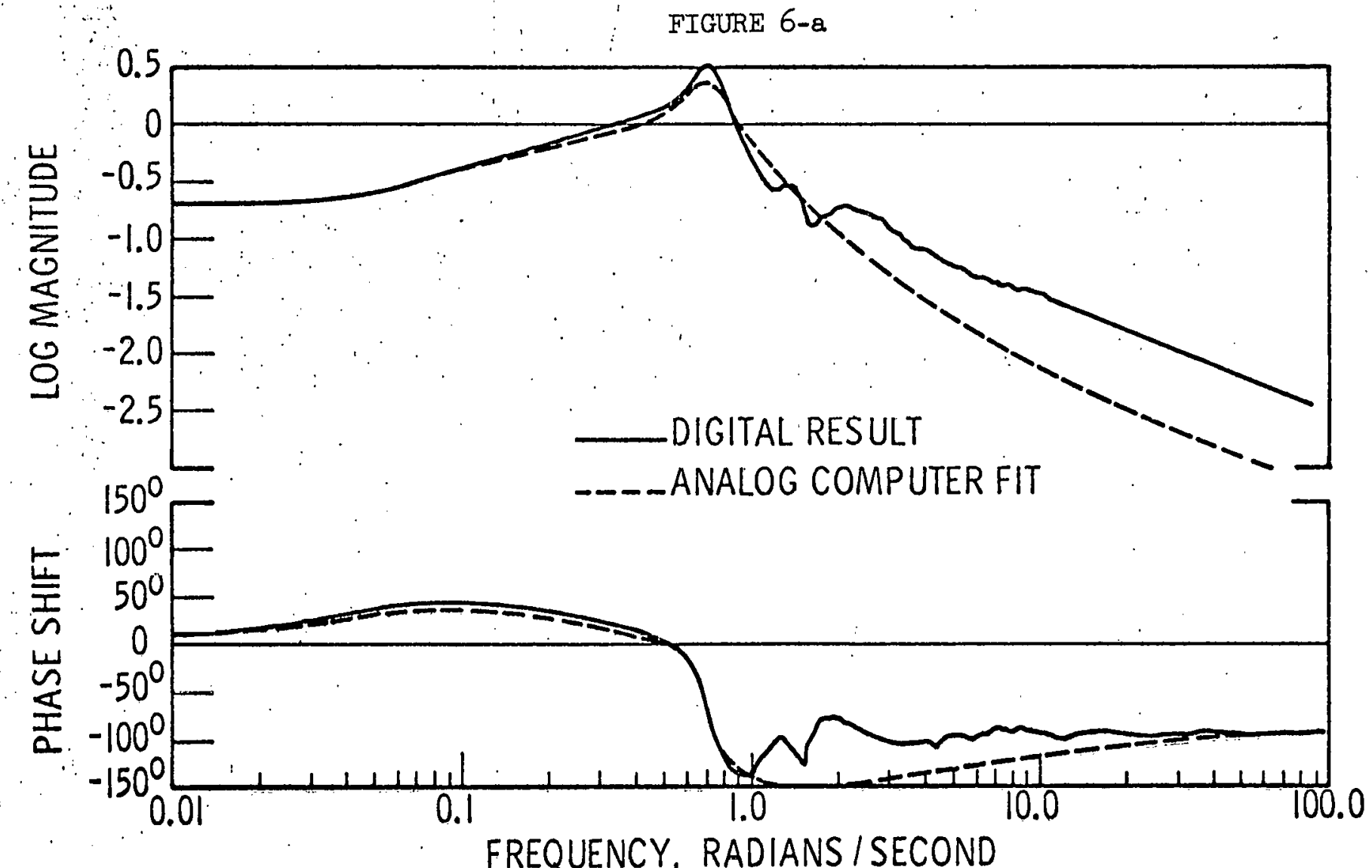

FREQUENCY RESPONSE OF THE WATER. LEVEL TRANSFER FUNCTION FOR A 50 PSI STEP DECREASE IN SYSTEM PRESSURE

E. D. SK. 322399-B 


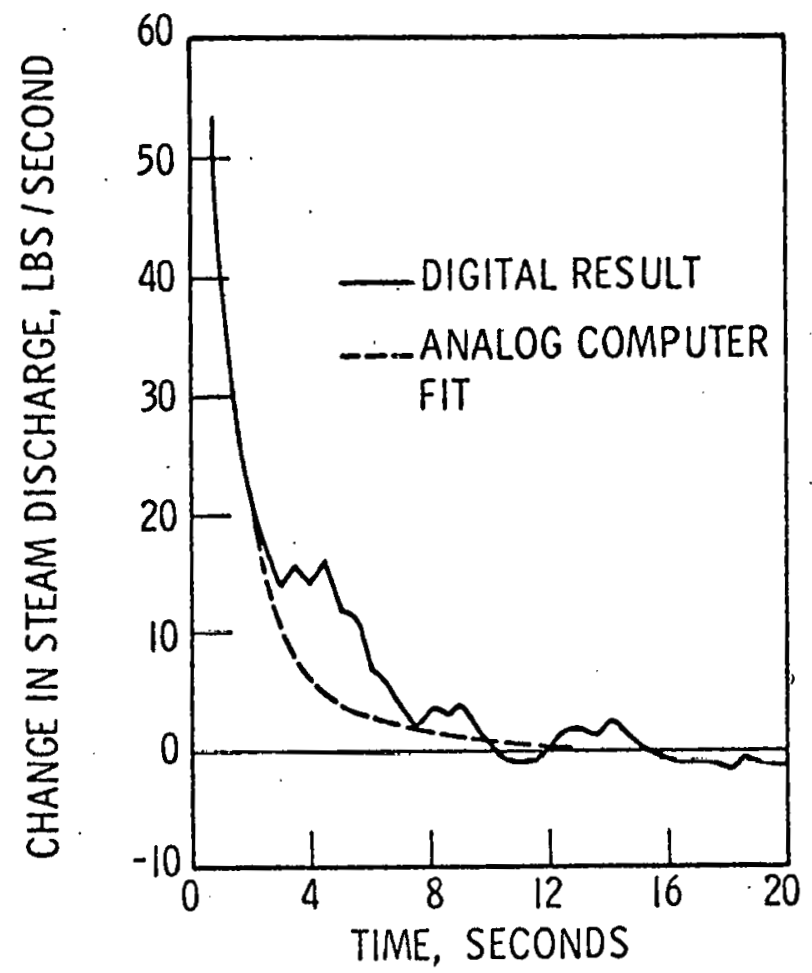

CHANGE IN STEAM DISCHARGE FOR A 50 PSI

STEP DECREASE IN SYSTEM PRESSURE FIGURE 7-a.

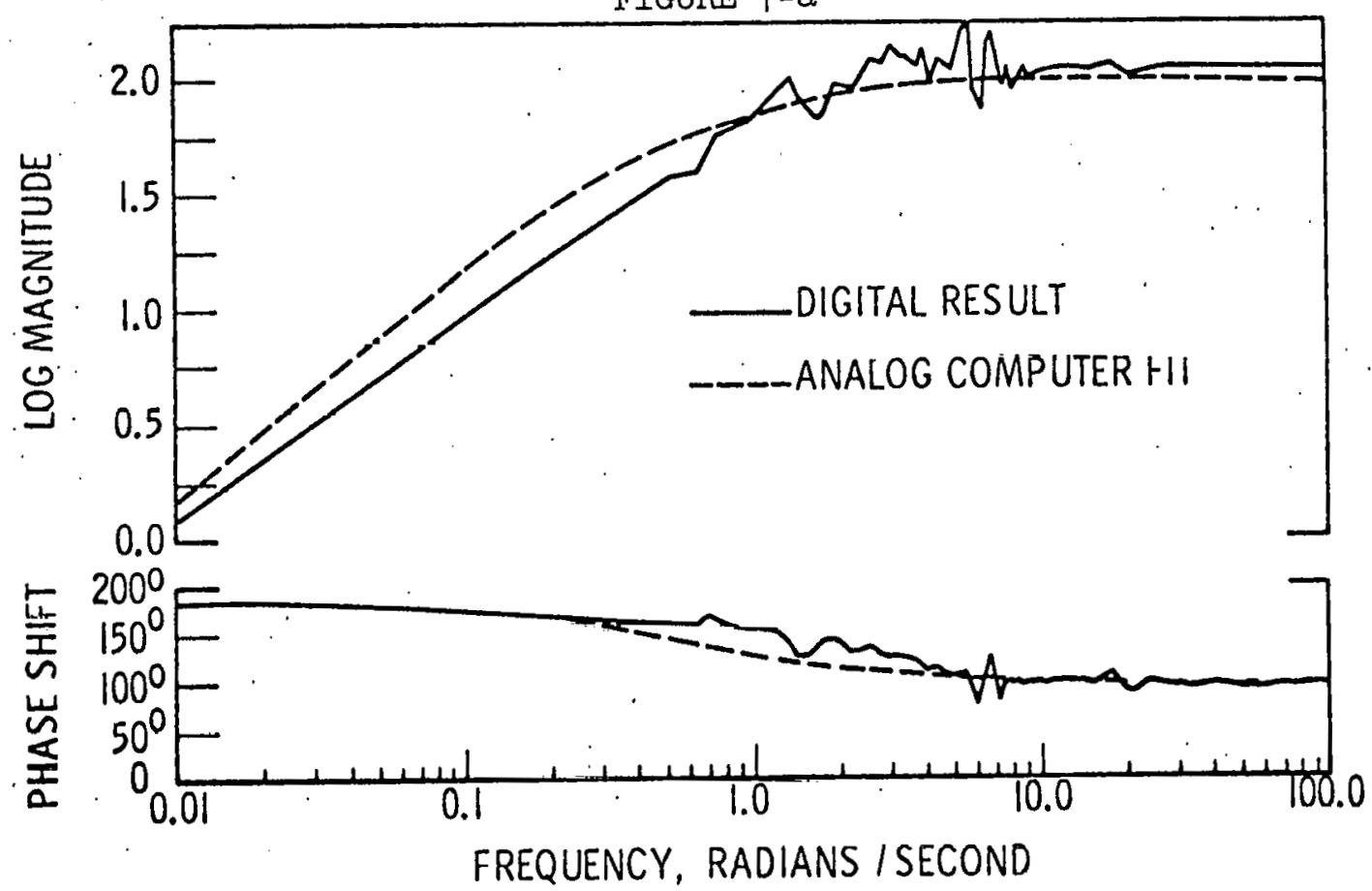

FREQUENCY RESPONSE OF THE STEAM DISCHARGE TRANSFER FUNCTION FOR A 50 PSI STEP DECREASE IN SYSTEM PRESSURE

E. D. SK. 322406-B 
curve-fitting techniques, the coefficients of the estimated transfer function are varied systematically until the closet possible fit between the tabulated frequency data and the approximating function ịs obtained. To check the correctness of the transfer function, appropriate computer program is employed to perform the inverse transformation so that the original time response can be reproduced and the accuracy of the transfer function verified. The six transfer functions for the recirculation loop are:

1) Water level transfer function calculated from time response due to a 10\% step increase in feedwater mass flow rate shown in Fig. 2-a,

$$
G_{1}=\frac{0.0244\left[\left(\frac{s}{0.2124}\right)^{2}-0.4879\left(\frac{s}{0.2124}\right)+1\right]\left[\left(\frac{s}{0.9764}\right)^{2}+0.2397\left(\frac{s}{0.9764}\right)+1\right]}{s\left[\left(\frac{s}{0.6938}\right)^{2}+0.1713\left(\frac{s}{0.6938}\right)+1\right]\left[\left(\frac{s}{0.2971}\right)^{2}+1.4893\left(\frac{s}{0.2971}\right)+1\right]}
$$

2) Steam discharge transfer function calculated from time response data due to a $10 \%$ step increase in feedwater mass flow rate shown in Fig.3-a,

$$
G_{2}=\frac{1.01361 s^{3}-4.6754 s^{2}+8.8797 s-7.8}{0.24024 s^{5}+3.03812 s^{4}+9.6408 s^{3}+11.8126 s^{2}+5.97 s+1}
$$

3) Water level transfer function calculated from time response data due to a 10\% step increase in system thermal power input shown in Fig。 4-a,

$$
-G_{3}=\frac{0.0713 s^{3}+0.02909 s^{2}+0.07328 s-0.003615}{s^{4}+0.4748 s^{3}+0.4890 s^{2}+0.1676 s}
$$

4) Steam discharge transfer function calculated from time response data due to a $10 \%$ step increase in system thermal power input shown in Fig. 5-a,

$$
G_{4}=\frac{54.28}{1+1.59 \mathrm{~s}}
$$

5) Water level transfer function calculated from. time response data due to 
50 psi. step decrease in system pressure shown in Fig. 6-a,

$$
G_{5}=-\frac{0.0875 s^{2}+0.4860 s+0.0234}{s^{3}+0.3772 s^{2}+0.5230 s+0.0868}
$$

6) Steam discharge transfer function calculated from time response data due to $50^{\circ}$ psi. step decrease in system pressure shown. in Fig。7-a,

$$
G_{6}=-\frac{151.13 \mathrm{~s}}{1+1.59 \mathrm{~s}}
$$

STEAM. DRUM. ANALOG MODEL

The mathematical model for the steam drum is based on a lumped-parameter representation of the saturated steam-water mixture in the steam generator drum. The fundamental equations and the derivation of the mathematical model are presented in Appendix 2。 It is shown that the system pressure variation can be determined in terms of the steam discharge rate from the recirculation loop, the steam discharge to the turbine, and the rate of change of water level by the following expressions:

$$
p^{*}=\frac{E^{*}-C_{1} M^{*}-c_{3} v^{*}}{c_{2} M_{0}+c_{4} v_{0}+C_{2} M^{*}+c_{4} v^{*}}
$$

where

$$
\begin{aligned}
& E^{*}=\int_{t_{0}=0}^{t}\left[\left(m_{d}-m_{s}\right) h_{g}-\frac{1}{J} p \frac{d V}{d t}\right] d t \\
& M^{*}=\int_{t_{0}=c}^{t}\left(m_{d}-m_{s}\right) d t
\end{aligned}
$$

WATER LEVEL CONTROLLER ANALOG

The water level controller configuration employed in this study consists of standard proportional and reset controls on water level deviation from a desired 
set point and the difference between the steam and feedwater mass flow rates.

The feedwater valve employed in the initial feedwater control scheme was driven full speed open or closed by an on-off signal. Although the control system performance was satisfactory for step changes in load demand, the on-off nature of the control signal caused a high frequency oscillation in feedwater flow. This attractively simple control scheme (shown in Fig。 8-a) did not adversely affect the performance of the steam generator; rather the high frequency oscillations. reduced the effect of drift in feedwater valve position. However, high frequency oscillation in feedwater flow is detrimental to the life of the feedwater valve and forms. a potential source of "unrest" and thermal shock for the steam generator.

After further analysis and consultation with control equipment manufacturers, the controller model shown in Fig. 8-b was selected for this level controller study. The valve positioner has built-in position feedback to eliminate drift in valve position. The manufacturer recommended a simple second-order transfer function. (Table I) to approximate the positioner behavior.

The electric-to-pneumatic converter can also be represented by a simple secondorder system having a natural frequency of 20 radians/second and a damping coefficient of 1.0 approximately. Consequently, the dynamic characteristics of the converter are neglected and the gain factor is incorporated in that of the valve positioner。

During the course of this study, it was revealed that the above-mentioned controller may be employed to control rather underdamped steam generator operating in the vicinity of the threshold of instability. However, the range of controller parameter variation required for stable operation would be unreasonably small. The addition of a first-order $\mathrm{lag}$, with an appropriate time constant $\tau$, on the water level signal (Fig. 8-b) damped out the system natural oscillations. It also served to improve the controller performance by increasing the range of controller parameter variation. 


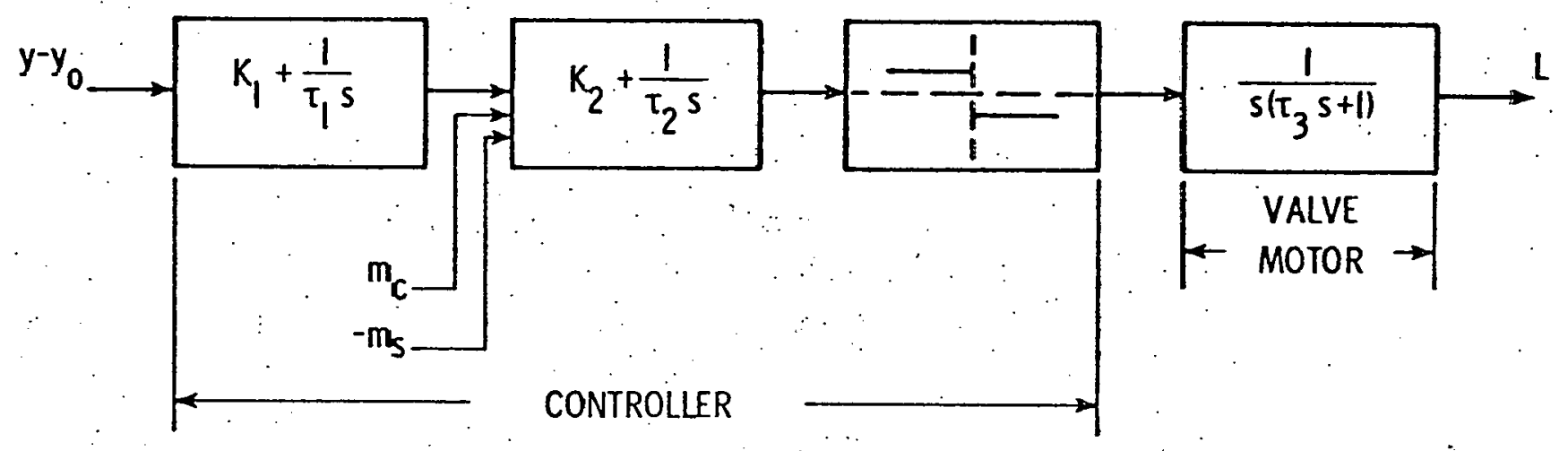

INITIAL STEAM GENERATOR LEVEL CONTROL SYSTEM

FIGURE 8-a

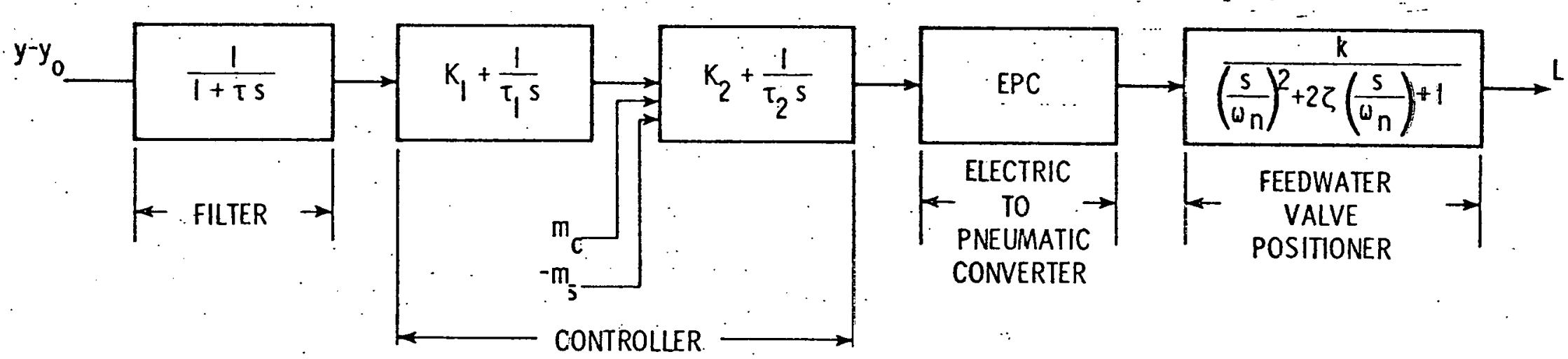

FINAL STEAM GENERATOR LEVEL CONTROL SYSTEM 


\section{FEEDWATER LINE ANALOG MODEL}

The analog model for the feedwater line relates the feedwater mass flow rate variation to variations in system pressure and feedwater valve lift. Since water is sufficiently incompressible, no time lag has been considered in this analog simulation. Derivation of the feedwater analog model is based on the inearization of the momentum equation for the feedwater flow through the steam generator feedpump, feedwater line and the control valve. Assuming small perturbations around steady state, it is shown that the feedwater mass flow rate variation is related to other system variables by the following simple relationship:

$$
m_{c}^{*}=C_{5} L^{*}+C_{6} p^{*}
$$

Details of the derivation are included in Appendix 3.

\section{STEAM MAIN TO TURBINE ANALOG MODEL}

The steam main-to-turbine analog model consists of a steam main model and a turbine governor valve model. In the development of the steam main analog model, the steam main volume is lumped with steam generator drum volume. It is further assumed that steam discharge through the main is 100\%.dry. Consequently, the inertia effects need not be considered. Applying the momentum equation to the steam flow from steam generator discharge nozzle to governor valve inlet nozzle, and assuming small perturbation around steady state, it is shown that the governor valve inlet pressure variation is related to other system variables as follows:

$$
\mathrm{p}_{\mathrm{n}}^{*}=\mathrm{c}_{7} \mathrm{p}^{*}+\mathrm{c}_{8} \mathrm{~m}_{\mathrm{s}}^{*}
$$

Details of this derivation are included in Appendix 4. In the development of the turbine governor valve model, it is reasonably assumed that the steam flow through the governor valve is critical, 1.e., that the steam flow discharge into the turbine is independent of the downstream pressure. It is shown, In Appendix 4, that the variation in steam mass Plow rate discharge to turbine is related to other system varlables as follows:

$$
\mathrm{m}_{\mathrm{s}}^{*}=c_{9} \mathrm{p}_{\mathrm{n}}^{*}+\mathrm{c}_{10} \frac{\mathrm{A}_{\mathrm{m}}^{*}}{\mathrm{~A}_{\mathrm{mo}}}
$$




\section{PRESENTATION OF RESULTS}

The steam generating unit and the water level controller were simulated on the analog computer as shown in Fig.9, using the analytical models developed in the previous section. Certain important plant parameters are presented in Table II. The water level control system was evaluated by applying step changes in the turbine governor valve area and observing the following time responses: water level, steam generator pressure, turbine valve nozzle inlet pressure, turbine mass flow rate, and the feedwater mass flow rate into and steam discharge out of the steam gnerator. The most important responses are the water level and feedwater mass flow rate. The first one gives an indication of the effectiveness of the control system in performing its main function. The second response shows the stability of the feedwater loop, which is the "fastest" loop in. the system and, as such, the most prone to exhibit unstable or underdamped behavior.

The effect of feedwater valve speed was first determined. Analog computer runs were conducted for different valve. speeds, ranging from 2 to 40 seconds full stroke time, without changing the controller parameter settings. Results of this study indicated that the effect of valve speed on controller performance was insignificant. A feedwater valve with 20 seconds f'ull stroke time was then selected since this is an acceptable value from the cost viewpoint.

The effect of controller parameter settings $K_{1}, K_{2}, \tau, \tau_{1}$ and $\tau_{2}$ was then studied. Analog computer runs, with special attention on system stability, were. conducted. Results of this study showed that the system performance is insensitive to variation in $\tau_{2}$. Values of $\tau_{2}$ smaller than 20 seconds were not recommended. by the equipment manufacturer; hence, $\tau_{2}$ was selected as equal to 20 seconds. Contruller parumeler settings $\mathrm{K}_{1}, \mathrm{~K}_{2}, \tau$ and $\tau_{1}$ strongly atitect the control system behavior. By varying these paramteters in a systematic way, a combination of parameters was found for which the system response to a step change in turbine governor valve area was an optimum. The definition of "optimal response" was based on the inspection of the time-response behavior (i.e. overshoot and response time) rather than a mathematical criterion. 

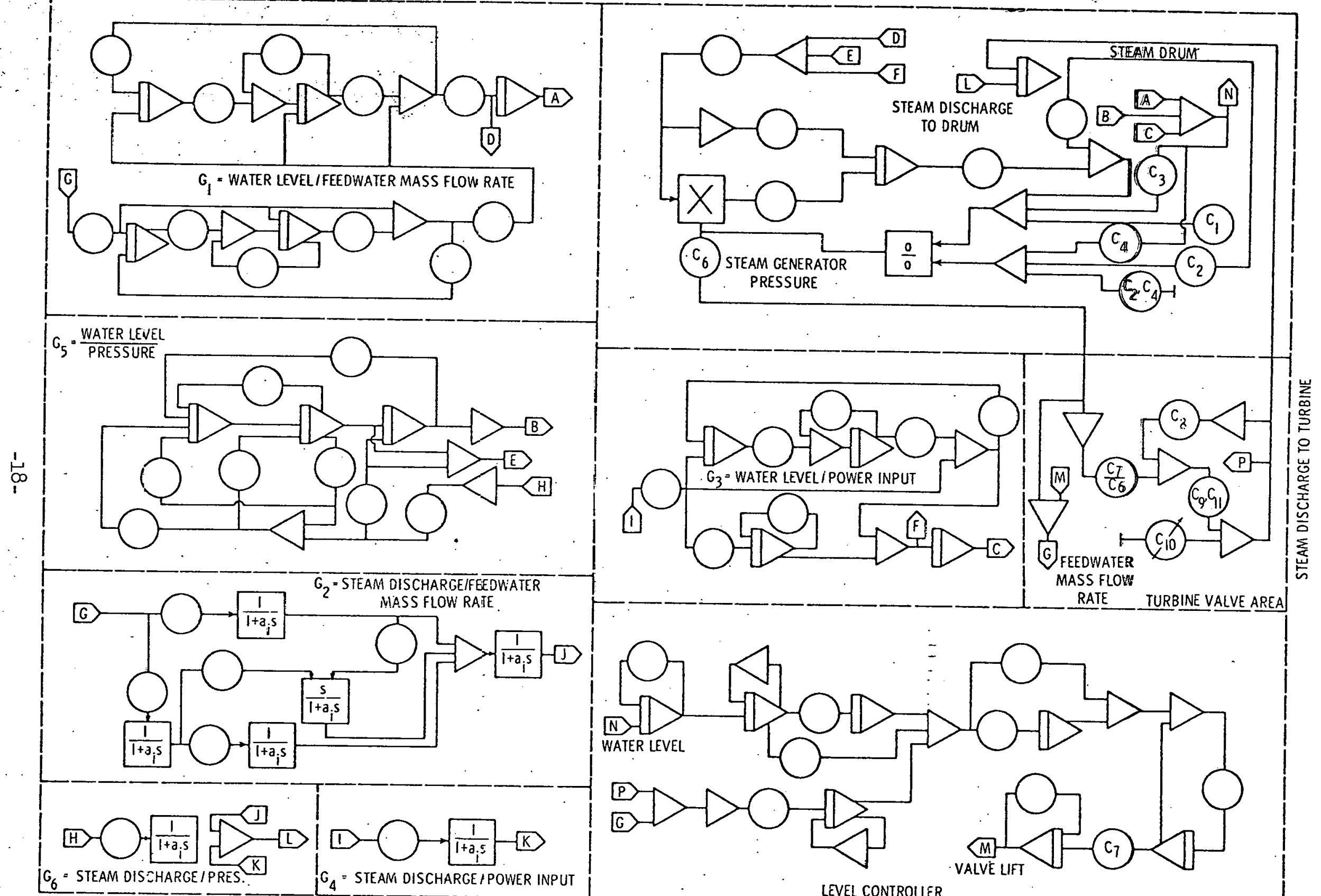
Based on operating experience, the flow response of the feedwater loop (without water. level and steam flow. rate signals) was considered acceptable when the overshoot was less than. $25 \%$ and the peak time not more than 2 seconds for a step change. in feedwater flow rate set point. In contrast, and in view of , the lack of sufficient experience with large steam generators of the type studied here, it is more difficult to establish a performance criteria for the water. level control system. However, it appears reasonable to require that the water level return to the set-point value within two minutes following a step change in turbine governor valve area.

Analog studies on the controller parameter $K_{2}$ indicate that the water level and feedwater flow response requirements impose the lower and upper limits,. respectively, for this parameter. However, there is large range over which $\mathrm{K}_{2}$ can be varied without an, noticeable affect on system response. The upper and lower. limits for the controller parameter $K_{2}$ were found to be equal to 25 and 100 respectively, which provides a reasonable freedom of final adjustment in the field.

Studies on the controller parameter $K_{1}$ indicate that ultimate restrictions on the value of this parameter are imposed by water level stability. However, the water level response requirement narrows the allowable region even further. The upper and lower limits of $K_{1}$ are found to be 0.625 and 0.39 .

Analog runs on the controller parameter $\tau_{1}$ st:ow that, similar to the case nf $K_{2}$, the water level and feedwater response requirements respectively impose the lower and upper limits of this parameter... Here, only a lower limit of $\tau_{1}=75$ seconds, was, established. The maximum possible value is best determined under actual operating conditions. However, an optimum response is achieved by choosing $\tau_{1}=100$ secunds. Control components for this optimal value are readily availablè.

The parameter $\tau$, the time constant of the first order lag (used to filter out the level signal natural oscillations), also exerts a large influence on system response: Analog: computer runs indicated. that the optimal value for $\tau$ is 5 seconds, with upper and lower limits of 10 and 2.5 seconds respectively. 
The present analog model can be employed to determine regions of stability and acceptable response, in the $K_{1}-K_{2}-\tau_{1}-\tau_{\text {ind }}$ space. As shown on. Fig. 10-a the loci. of $K_{1}$ and $K_{2}$ values with $\tau_{1}$ as a parameter and $\tau=0$ for system operating at the threshold of instability (sustained water level oscillations) can be plotted. The value of $\tau=0$ constitutes the most conservative case since values of $\tau>0$ improves the system stability and transient response. From these curves; a region of stable operation. (hatched area in Fig. 10-b) can be defined. In a similar manner, the loci of points which barely satisfy the response requirements can be plotted and a region of acceptable operation defined (cross-hatched area)。In Fig. 10-b, the stability and response limits are plotted for $\tau_{1}=50$ seconds only。

Typical analog computer water level responses for a variety of controller parameter settings $K_{1}, K_{2}, \tau_{1}$ and $\tau$ are shown in $F 1 g \circ 11,12,13$, and 14 . These characteristics are determined for a 10\% step increase in turbine governor valve flow area. Fig. 15 shows the feedwater loop response for a step change in feedwater set point. In Fig 16, the water level. behavior is shown for a step change in level set point. The time variation of the six most important steam generator variables is shown in Fig. 17 for a 10\% step increase in turbine governor valve admission area for optimum controller settings.

The control system was tested for susceptibility to drift and noise. Analog results have shown that the control system is not greatly affected by drift in feedwater valve position or controller input signals.. The level variation approaches to zero after a step-change in turbine governor valve area and remains at zero. The feedwater flow rate approaches a new steady-state value and then holds constant. Further analog runs, with noise injected into the system by a noise-generator. have indicated that the control system is not particularly affected by the noise in feedwater valve positioner or level and flow measurement signals. 


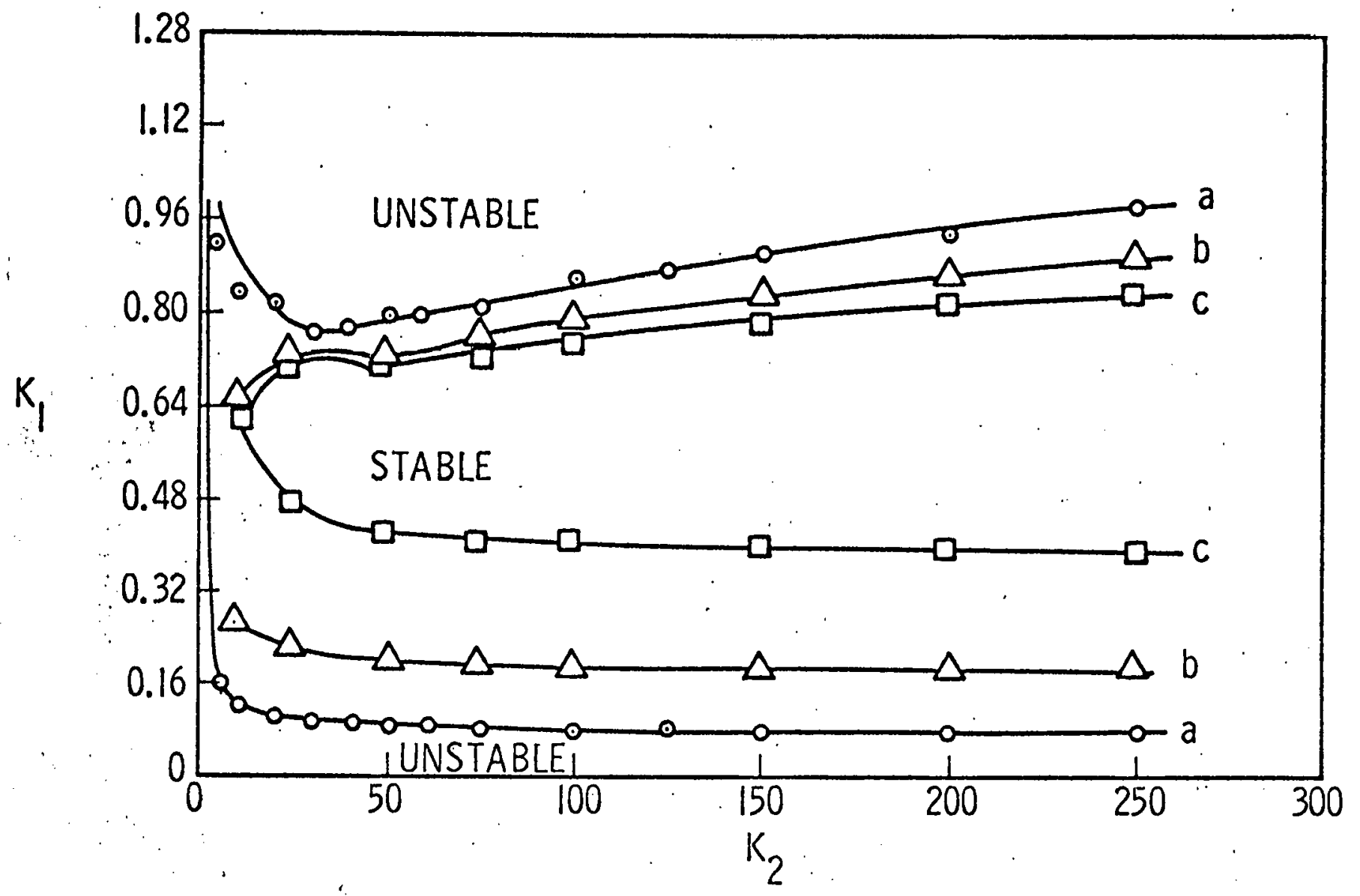

STABILITY LIMITS AS A FUNCTION OF $K_{1}$ AND $K_{2}$ FOR $\tau_{2}=20 \mathrm{SEC}$ $\tau=0$ SEC. AND
(a) $\tau_{1}=50 \mathrm{SEC}$.
(b) $\tau_{1}=25 \mathrm{SEC}$.
(c) $\tau_{1}=12.5 \mathrm{SEC}$.

E. D. SK. 322392-B

FIGURE 10-a 


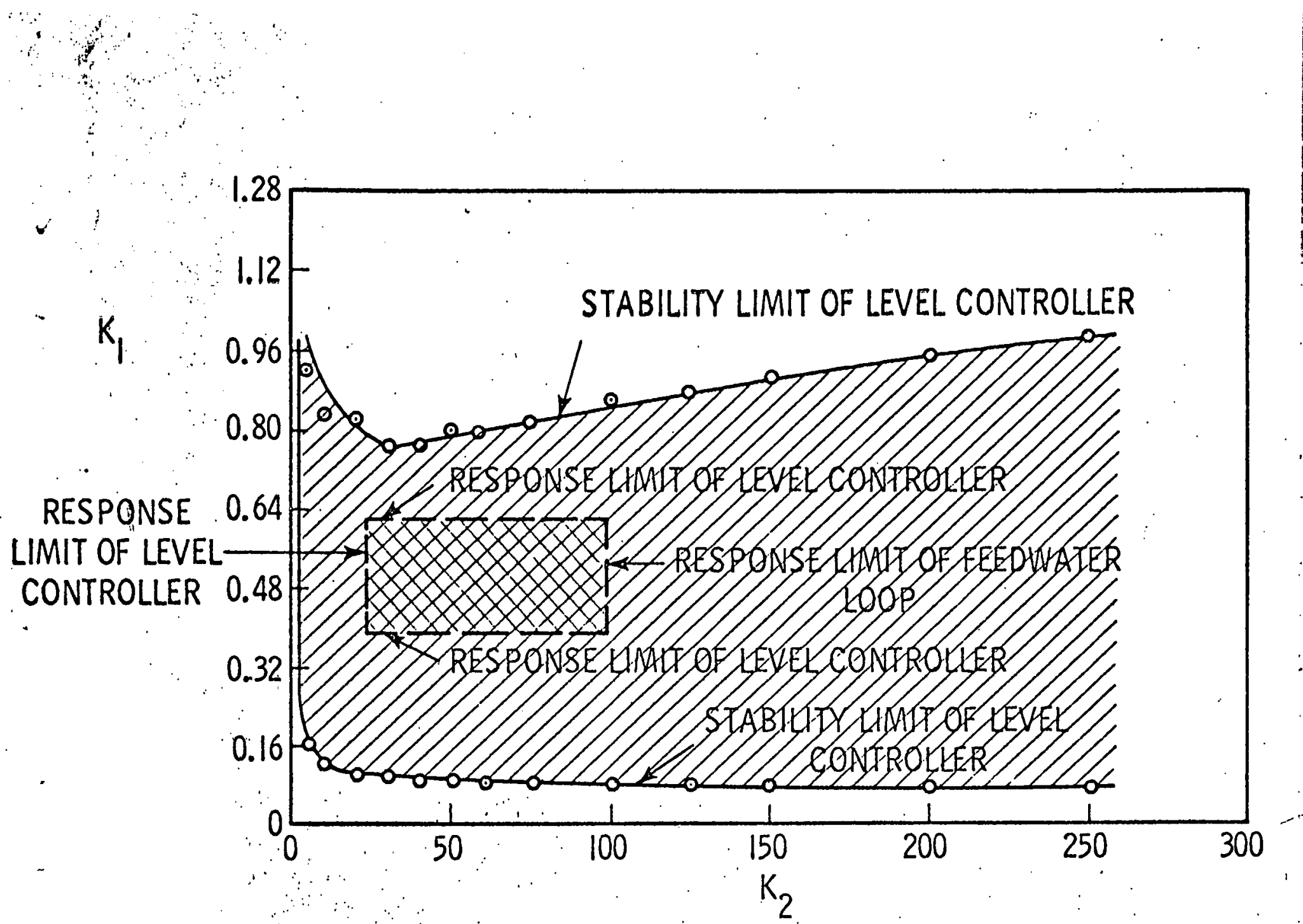

STABILITY AND RESPONSE LIMITS AS A FUNCTION OF $\mathrm{K}_{1}$ AND $\mathrm{K}_{2}$ FOR $\tau_{1}=50$ SEC., $\tau_{2}=20$ SEC.,$\tau=0$ SEC.

E. D. SK. 322396-B

FIGURE 10 b 

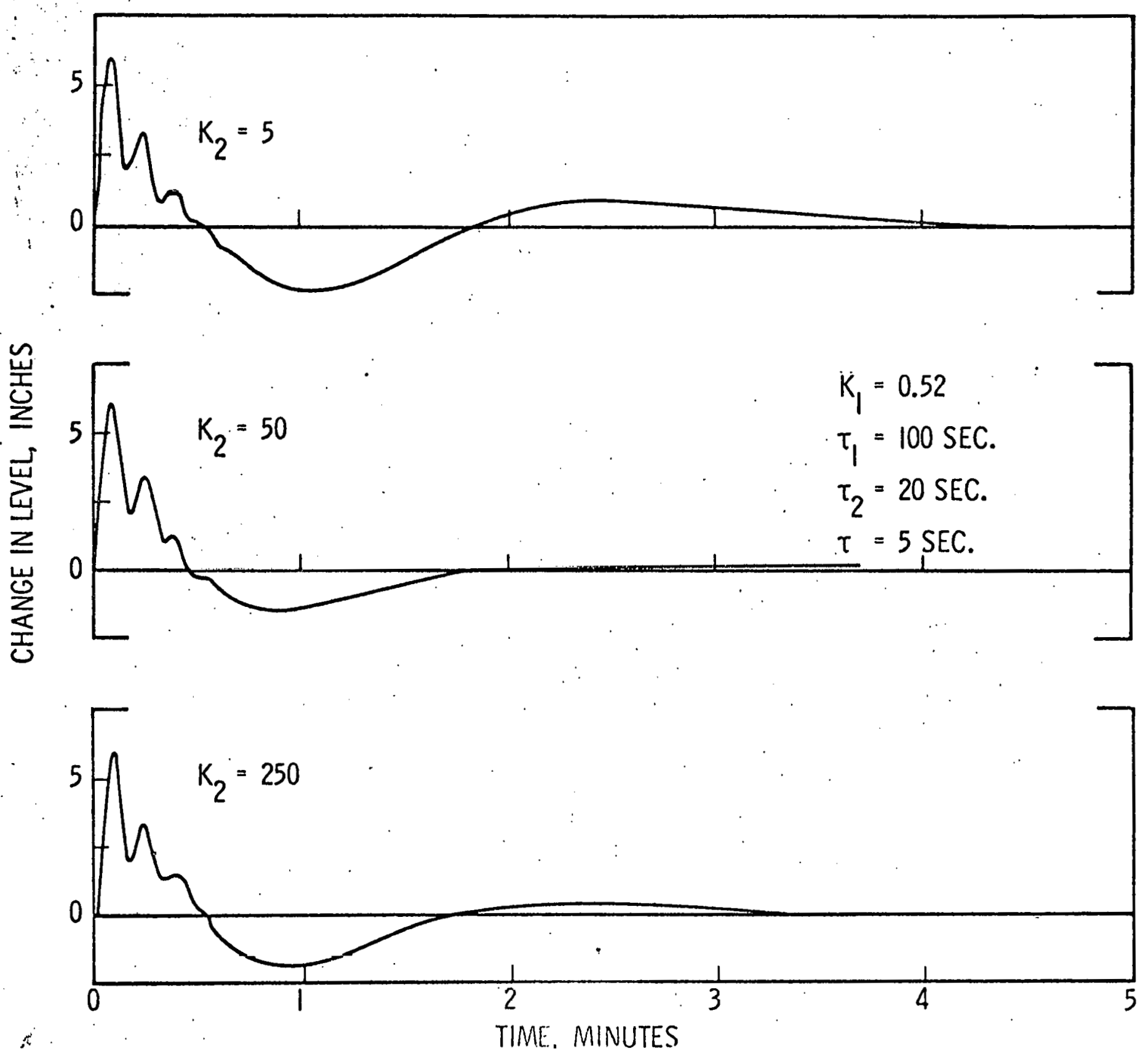

STEP RESPONSE OF. STEAM GENERATOR WATER LEVEL CHANGE FOR A $10 \%$ STEP INCREASE IN TURBINE GOVERNOR VALVE AREA FOR DIFFERENT VALUES OF $\mathrm{K}_{2}$

E. D. SK. $322391-B$

FIGURE 12 


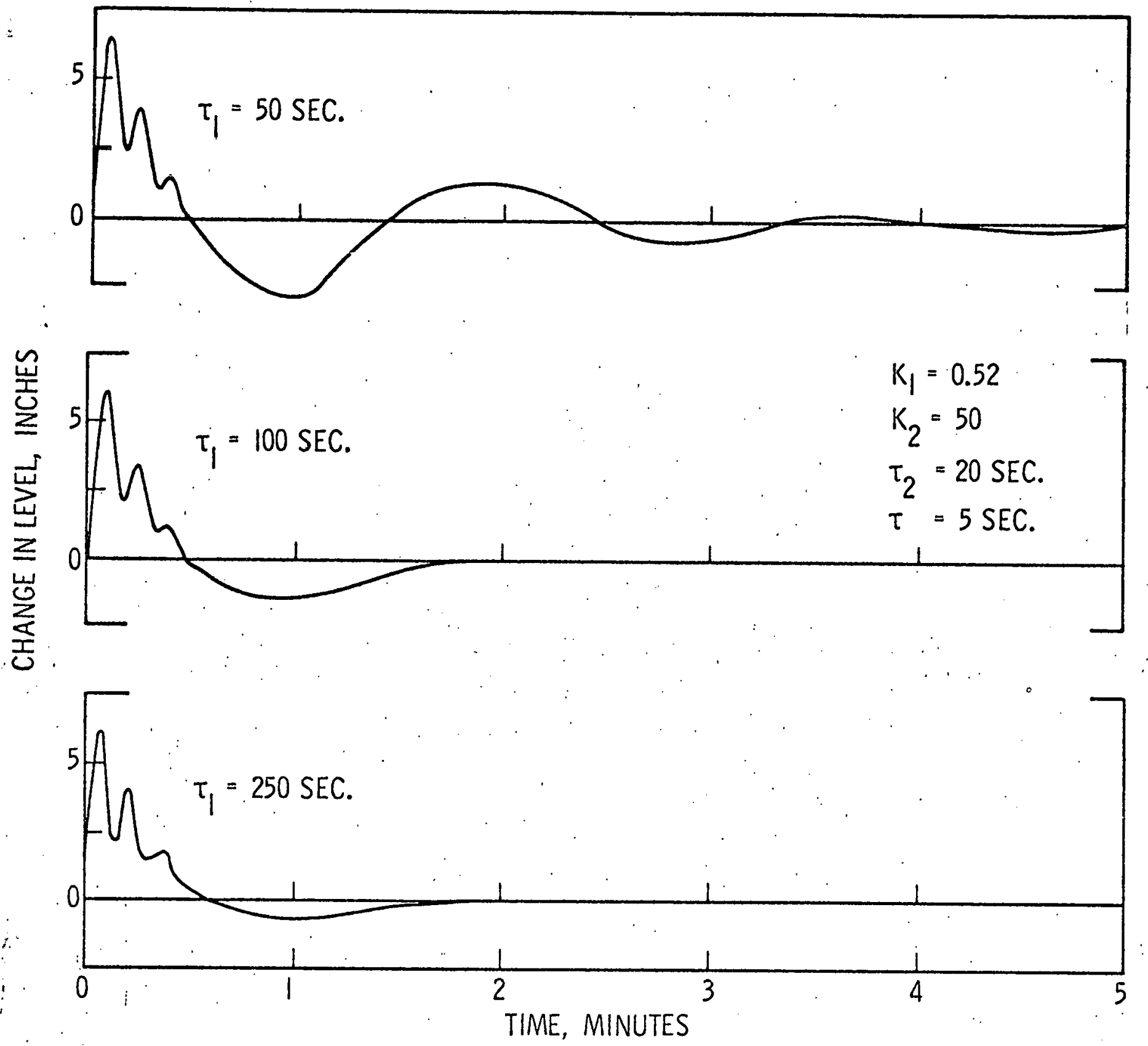

STEP RESPONSE OF STEAM GENERATOR WATER LEVEL CHANGE FOR A $10 \%$ STEP INCREASE IN TURBINE GOVERNOR VALVE AREA FOR DIFFERENT VALUES OF $\tau_{1}$

E. D. SK. $322395-B$

FIGTRE 13 

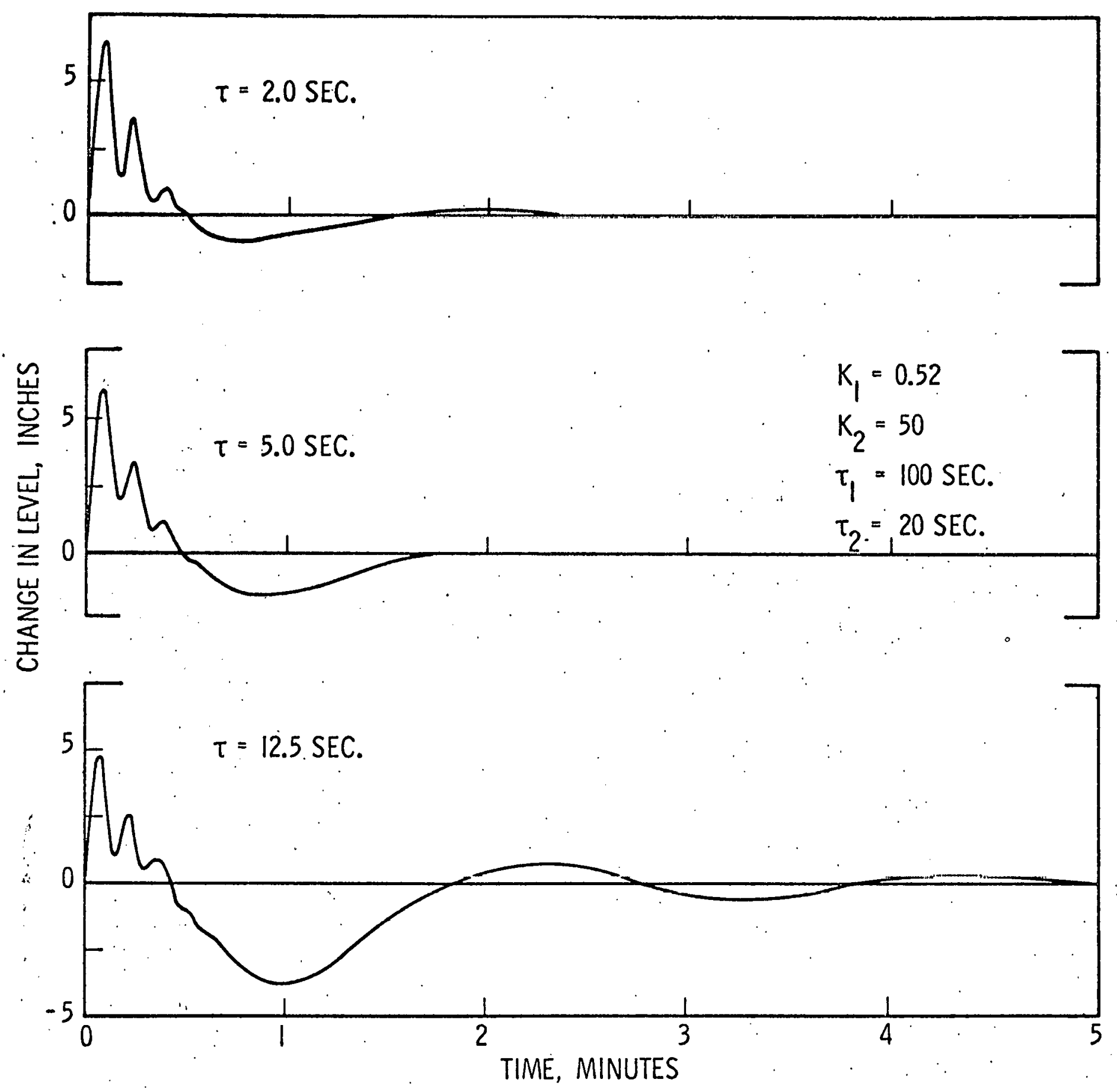

STEP RESPONSE OF STEAM GENERATOR WATER LEVEL CHANGE FOR A $10 \%$ STEP INCREASE IN TURBINE GOVERNOR VALVE AREA FOR DIFFERENT VALUES OF $\tau$

E. D. SK. 322398-B 


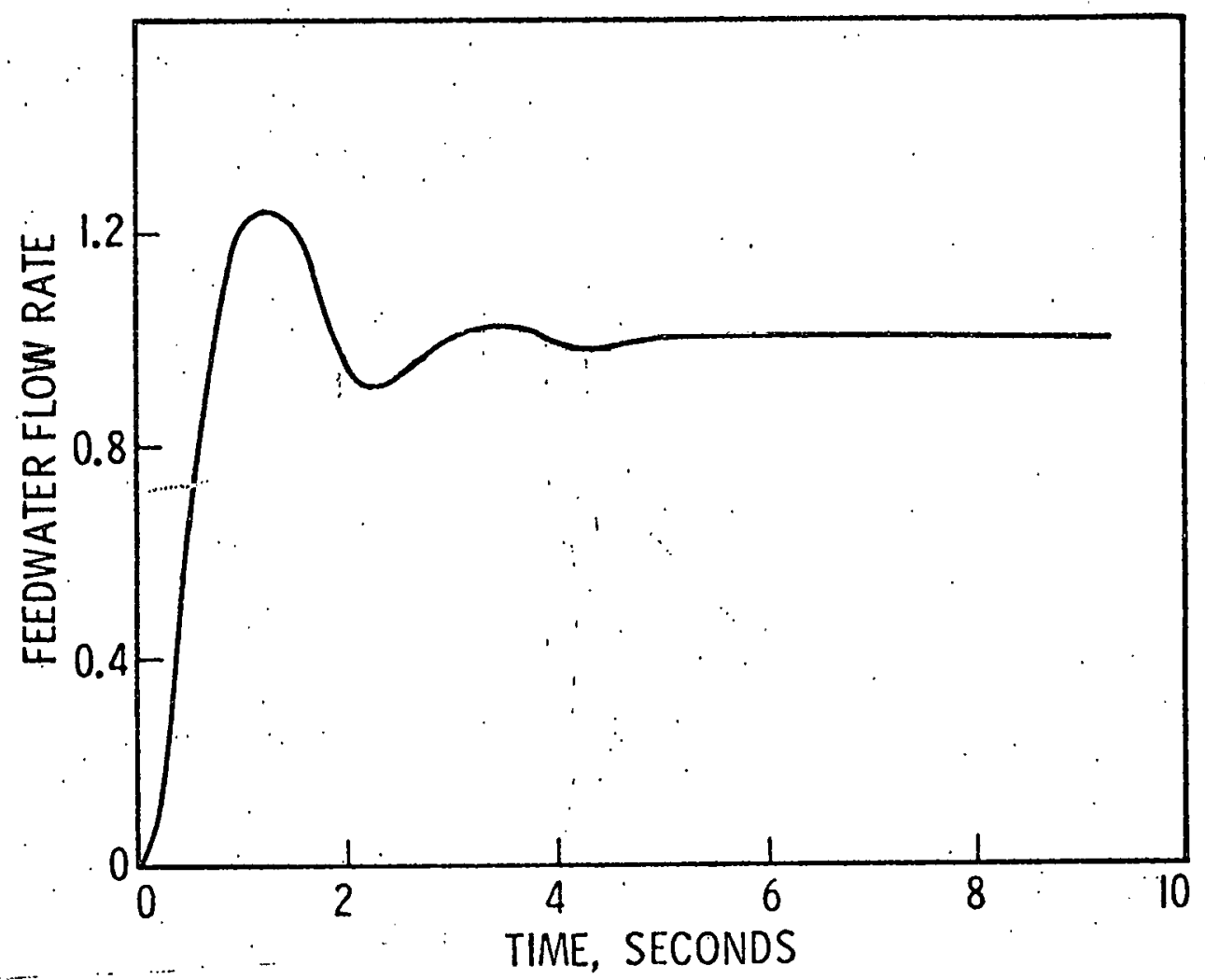

RESPONSE OF THE FEEDWATER LOOP FOR

A UNIT STEP CHANGE IN SET POINT

FIGURE 1.5

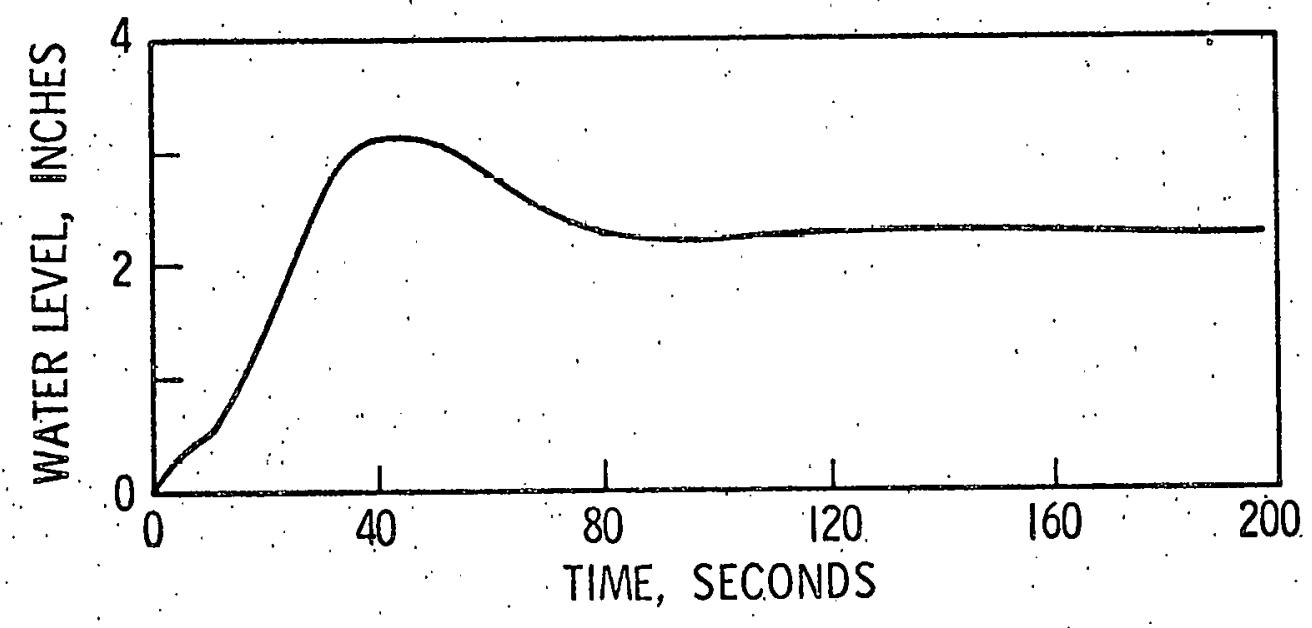

RESPONSE OF THE WATER LEVEL CONTROL SYSTEM FOR A STEP CHANGE OF 2.25 INCHES IN SET POINT

E. D. SK. 322393-B 

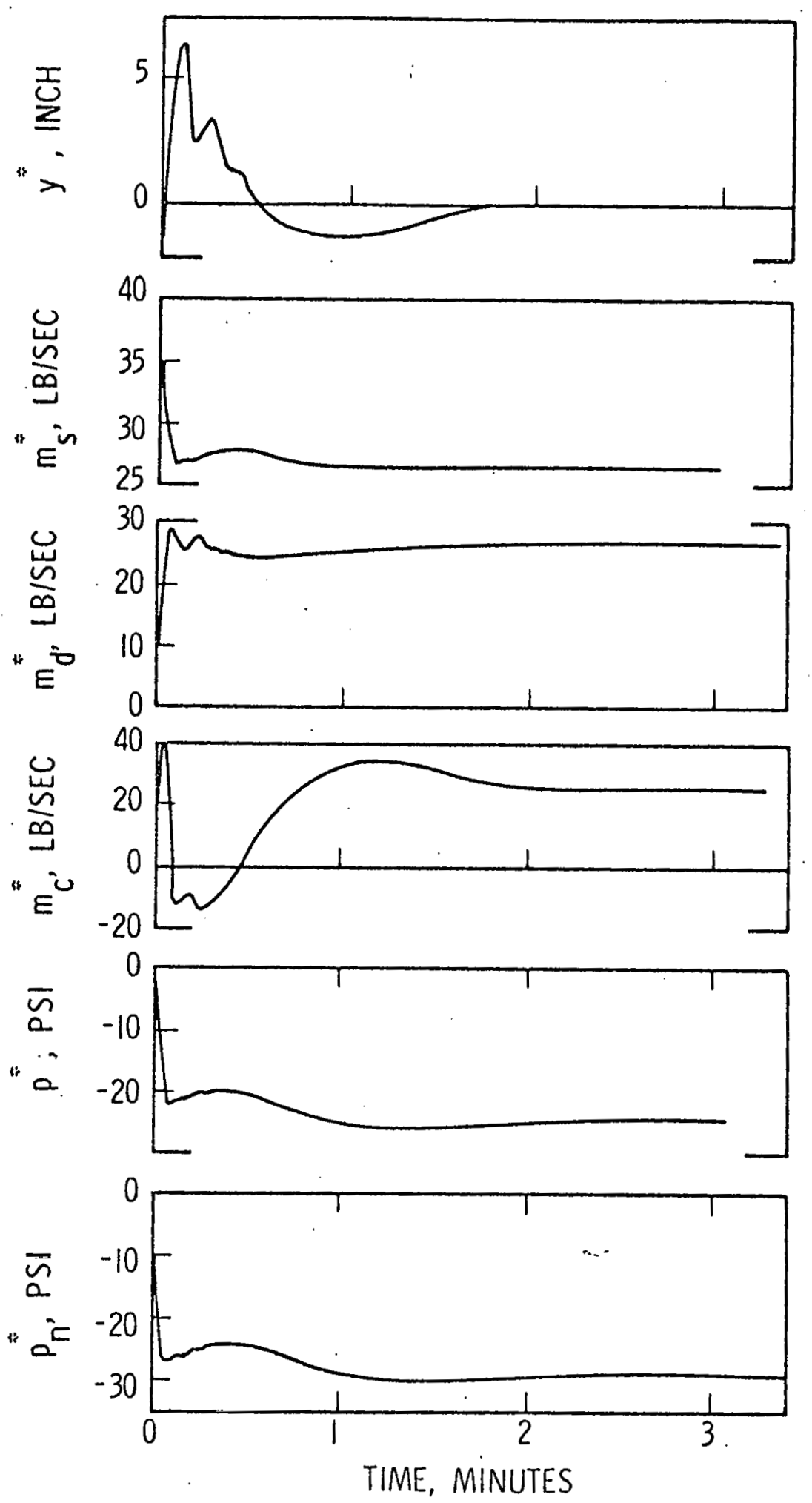

STEP RESPONSE OF STEAM GENERATOR

SIX MOST IMPORTANT VARIABLES FOR A 10\% STEP INCREASE IN TURBINE GOVERNOR VALVE AREA FOR OPTIMUM CONTROLLER SETTINGS 


\section{ACKLNOWLEDGEMENT}

The authors wish to express their appreciation to Messrs. J. P. Cunningham, J. S. Moore and R. F. von Hollen of Westinghouse Atomic Power Division for their assistance in the development of parts of the model and the transfer functions employed in the analysis. The authors are also indebted to Mr. G. Rouvalis of Hagan Controls, Inc. for his assistance in the development of feedwater valve positioner transfer function. 


\section{REFERENCES}

1. "An Electronic Feedwater Control System for the Experimental Boiling Water Reactor" by R. H. Morse and R。.N. Brey, Jr., Preprint 36, Session XVII, Nuclear Engineering and Science Conference. March 17 to 21, 1958.

2. "Dynamic Analysis of the Operation of EBWR at $100 \mathrm{MW}$ " by N. Suda and F. Rehbach, Argonne National Laboratory, ANL-6478, December 1961 .

3. "A Space-Dependent Dynamic Analysis of Boiling Water Reactor Systems" by A. N. Nahavandi and R. F。 von Hollen, to be published in the Journal of the American Nuclear Society, Nuclear Science and Engineering.

4. "Steam Water Pressure Drop and Critical:Discharge Flow-A Digital Computer Program" by WoA. Massena, General Electric, Hanford Atomic Products Operation, Richland, Washington, Report No. HW-65706, 1960.

5. "Lecture Notes on Heat Extraction from. Boiling Water Power Reactors" by $P_{0} A_{0}$ Lottes, M。 Petric and J。F。 Marchaterre, October 1959, Report No. ANL-6063, Argonne National Laboratory, P。O.Box 299, Lemont, Illinois. 
APPENDIX 1 - DETAIISS OF RECIRCULATION LOOP SPACE-DEPENDENT DIGITAL MODEL

The Fundamental Equations

As mentioned earlier, the independent variables employed in the recirculation loop digital model are length along the flow path $z$ and time $t$. The main dependent variables are defined as those variables whose values are calculated by solving a time-dependent differential equation. These variables are of primary importance in the determination of system transient behavior. The auxiliary dependent variables are defined as those vartables whose values may be calculated in terms of the main dependent variables, using certain algebraic equations. These variables, as their name implies, facilitate calculation of the main dependent variables. The main dependent variables employed in the recirculation loop digital model are as follows:

The coolant enthalpy (in the subcooled region), $h$

The coolant vold fraction (in the boiling region), $\alpha$

The U-tube metal temperature, $\mathrm{T}_{t}$

The liquid velocity at the inlet to the downcomer, $u_{1}$

The water level, $y$

Any recirculation loop dependent variable not included in the above list is classified as an auxiliary dependent variable. The recirculation loop is divided into a finite number of elements of length $\Delta z$ having a uniform crosssection. The length increment is sufficiently small so that the properties within each element could be considered uniform everywhere except at the inlet where the fluid enters from the adjacent element. Expansions and contractions in flow cross-section are assumed to be located at the inlet or outlet of an element.

In the development of conservation equations, allowance is made for the feedwater flow and steam discharge out of the recirculation loop. In the development of energy equation for the coolant flow in the recirculation 100p, the effect of the potential and kinetic energles, as well as the contribution of frictional losses, pressure time derivative and pressure gradient, are 
small enough to be neglected. Moreover, heat conduction along the U-tubes and the coolant flow path, as well as the heat transfer between the coolant and the steam generator vessel, are also neglected. In the derivation of momentum equations, however, the effect of frictional forces is important and is considered. The contribution of frictional losses is incorporated in the form of empirical pressure drop relationships. The "equivalent length" . concept is used in the calculation of pressure drop in the U-tube support plates, swirl vane steam separator and U-turns. In this section, a summary of the finite difference equations employed in the recirculation loop digital model is presented. The derivations are detalled in Reference ( $\underline{3}$ )and will not be repeated here.

The coolant enthalpy in any subcooled element is obtained from the energy equation,

$$
\left(\frac{d h_{w}}{d t}\right)_{j}=\frac{1}{\rho_{w}(\Delta z)_{j}}\left[\frac{A_{j-1}}{A_{j}} \cdot \rho_{w} \cdot\left(h_{w} u_{w}\right)_{j-1}-\rho_{w}\left(h_{w} u_{w}\right)_{j}+Q_{j}(\Delta z)_{j}+\frac{m_{j e} h_{j e}}{A_{j}}\right]
$$

The heat transfer rate per unit volume $Q_{\mathrm{g}}$ is zero at every point in the recirculation loop except in the heating zone where it is given by,

$$
Q_{j}=\frac{A_{t h}^{\prime}}{A_{h}^{\prime}}\left(U_{t h}\right)_{j}\left[\left(T_{t}\right)_{j}-T_{h}\right]
$$

The coolant void fraction in any bolling element is computed from the continuity equation,

$$
\begin{aligned}
\left(\frac{d \alpha}{d t}\right)_{j}=\frac{1}{\left(\rho_{g}-\rho_{f}\right)(\Delta z)_{j}} & \left\{\frac{A_{j-1}}{A_{j}}\left[\alpha \rho_{g} \gamma+(1-\alpha) \rho_{f}\right]_{j-1}\left(u_{f}\right)_{j-1}\right. \\
& \left.-\left[\alpha \rho_{g} \gamma+(1-\alpha) \rho_{f}\right]_{j}\left(u_{f}\right)_{j}+\frac{m_{j e}}{A_{j}}\right\} \\
& -32-
\end{aligned}
$$


The U-tube metal temperature is derived from the application of energy equation to a tube element,

$$
\frac{d T_{t}}{d t}=\frac{P}{A_{t}^{\prime} \rho_{t}\left(c_{t}\right)_{j}}-\frac{A_{t h}^{\prime}\left(U_{t h}\right)_{j}}{A_{t}^{\prime} \rho_{t}\left(c_{t}\right)_{j}}\left[\left(T_{t}\right)_{j}-T_{h}\right]
$$

The water level on top of the downcomer is obtained from the application of the continulty equation to the downcomer element adjacent to the watersteem interface,

$$
\frac{d y}{d t}=\frac{A_{r i}}{A_{d}}\left(1-\alpha_{r i}\right) u_{r i}-u_{d c}
$$

The coolent enthalpy for this element remains equal to saturated liquid. enthalpy $h_{f}$. The liquid velocity at the inlet to the downcomer is obtained from the pressure balance equation, derived by integrating the momentum equation around the recirculation 100p,

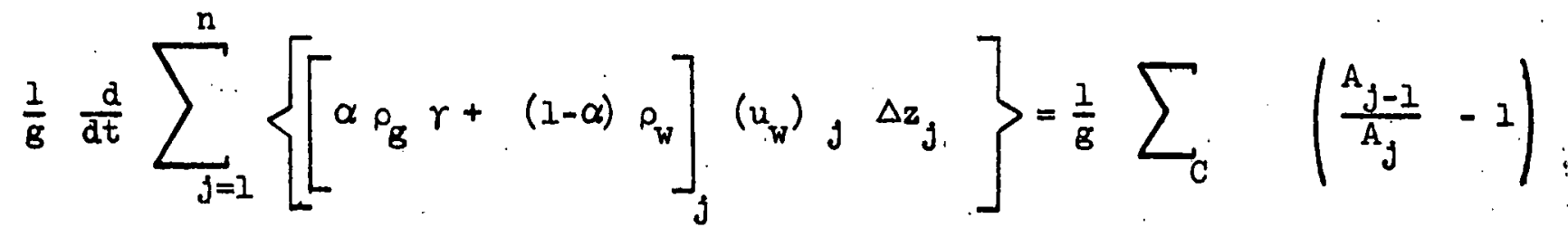

$\left[\alpha \rho_{g} \gamma^{2}+(1-\alpha) \rho_{w}\right]_{j-1}\left(u_{w}\right)_{j-1}^{2}+\frac{1}{g} \sum_{E}\left(1-\frac{A_{j}}{A_{j-1}}\right)\left[\alpha \rho_{g} \gamma^{2}+(1-\alpha) \rho_{w}\right]_{j 1}\left(u_{w}\right)_{j 1}^{2}$ $-\sum_{j=1}^{n}\left\{F_{j} \Delta z_{j}^{\prime}+\left[\alpha \rho_{g}+(I-\alpha) \rho_{w}\right]_{j} \Delta z_{j} \cos \theta_{j}\right\}+$ $\frac{1}{8} \sum_{t} \frac{1}{\rho_{j e}} \frac{m_{j e}}{A_{j} A_{j e}}\left|m_{j e}\right|+\frac{1}{g} \sum_{t} \frac{I}{\rho_{j e}} \frac{m_{j e}}{A_{j-I} A_{j e}}\left|m_{j e}\right|$ 
The liquid velocity in any subcooled element is calculated in terms of the liquid velocity in the upstream element from the continuity equation,

$$
\left(u_{w}\right)_{g}=\frac{A_{j-1}}{A_{j}}\left(u_{w}\right)_{j-1}+\frac{m_{j e}}{\rho_{w} A_{j}}
$$

The liquid velocity in any boiling element is obtained by eliminating the time rate of change of the void fraction between the continuity and energy equations,

$$
\begin{aligned}
& \left(u_{f}\right)=\left\{B_{1} \frac{A_{j-1}}{A_{j}}\left[\alpha \rho_{g} r+(1-\alpha) \rho_{f}\right]_{j-1}\left(u_{f}\right)-B_{j-1} \frac{A_{j-1}}{A_{j}}\left[\alpha \rho_{g} h_{g} r+(1-\alpha) \rho_{f} h_{f}\right]_{j-1}\right. \\
& \left.\left(u_{f}\right)_{j-1}+B_{1} \frac{m_{j e}}{A_{j}}-B_{2} \frac{m_{j e} h_{j e}}{A_{j}}-B_{2} Q_{j}(\Delta z)_{j}\right\} /\left\{B_{1}\left[\alpha_{g} r+(1-\alpha) \rho_{f}\right]_{j}\right. \\
& -B_{2}\left[\alpha \rho_{g} h_{g} \gamma+(1-\alpha) \quad \rho_{f} h_{f}\right] \\
& B_{1}=\rho_{g} h_{g}-\rho_{f} h_{f} \text { and } B_{2}=\rho_{g}-\rho_{f}
\end{aligned}
$$

The steam mass flow rate discharge from the riser is given by,

$$
m_{r 1}=A_{r 1} \alpha_{r 1} \rho_{B} \gamma_{r 1} u_{r 1}
$$

In the pressure balance equation, the momentum flux at the ln let to an element j (terms with subscript $j 1$ ) is calculated by applying the continuity and energy equation to the flow cross-section between two adjacent elements (3).

$-34-$ 
Modified Armand correlation and equilibrium equations between phases are employed to relate the void fraction, slip ratio, steam quality and system pressiure (4),

$$
\begin{aligned}
& \alpha=\frac{(0.833+0.167 x) \times v_{g}}{(1-x) v_{f}+x v_{g}} \\
& r=\frac{x v_{g}(1-\alpha)}{\alpha v_{f}(1-x)}
\end{aligned}
$$

The frictional pressure drop for subcooled flow is calculated in accordance with accepted procedures,

$$
F_{\text {sp }}=f \frac{\rho_{w}}{D} \frac{u_{w}^{2}}{2 g}
$$

For non-heated regions,

$$
f=f_{\text {Iso }}=.0055 \cdot\left[1+\left(20,000 \frac{R}{D}+\frac{10^{6}}{N_{R}}\right)^{1 / 3}\right]
$$

For heated regions;

$$
\mathbf{f}=(1-0.001 \Delta T) f_{180}
$$

The frictional pressure drop for two-phase flow is computed by Armand method $(\underline{4})$,

$$
F_{t p}=K F_{s p}
$$

where

$$
\begin{array}{ll}
K=\frac{(1-x)^{2}}{1.42}, & \text { for } 0.39<1-\alpha<1.00 \\
K=\frac{0.478(1-x)^{2}}{(1-\alpha)^{2.2}} & \text { for } 0.10<1-\alpha \leq 0.39 \\
K=\frac{1.73(1-x)^{2}}{(1-\alpha)^{1.64}} & \text { for } 0.00<1-\alpha \leq 0.10 .
\end{array}
$$

The overall heat transfer coefficient between $\dot{U}$-tube and the coolant in recirculation loop is calculated by adding the tube and scale deposit thermal conductive resistances and the film convective resistance in accordance with standard heat transfer procedures. The film heat transfer coefficient is obtained from the Jens-Lottes equation (ㄷ). 
The Method. of Solution

The fundamental equations presented above are solved numerically by means of the "Modified-Euler" integration process combined with appropriate iteration procedures. Numerical calculations are performed on an IBM-7094 digital computer. The computational scheme, including a discussion of the stability of the numerical technique, is presented in Reference ( 3 ) and will not be repeated here, in. full. detail. It suffices to say that starting from the initial values of the dependent variables, the "Modified-Euler" integration method is used to compute. the updated values of the main dependent variables including the coolant enthalpy in subcooled flow regions, coolant void fraction in boiling regions, U-tube metal temperature and water level (except for the liquid velocity at the inlet to the downcomer) employing Equations ( $A-1, A-3, A-4$ and $A-5)$. The updated value of the liquid velocity at the iniet to the downcomer is computed from Equation $(A-6)$ by a trial and error iterative technique. The distribution of the liquid velocity throughout the system, essential to this trial and error solution, is obtained from Equations (A-7 and A-8)。 In the meanwhile, the algebraic equations presented above serve to calculate the updated values of the auxiliary dependent variables. The updated values of the dependent variables are then taken as the initial values of the next time step, and the numerical procedure is repeated until final problem time is reached.

\section{APPENDIX 2 - DETAILS OF STEAM DRUM ANALOG MODEL}

The steam drum analog model is derived by the application of continuity and energy equations to the steam-water mixture in the steam generator drum. Saturated dry steam. leaving the recirculation loop enters into the drum at a rate $m_{d}$. Saturated dry steam flows out of the steam drum into the steam main at a rate $m_{s}$. Furthermore, in view of the water level variation, the steam-liquid volume in the steam drum is a time-dependent function. The continuity and energy equatione for the oteam drum, in a lumped-parameter form, take: the following form:

$$
\begin{aligned}
& \frac{d}{d t}\left(M_{f}+M_{g}\right)=m_{d}-m_{s} \\
& \frac{d}{d t}\left(M_{f} h_{f}+M_{g} h_{g}\right)-\frac{V}{J} \frac{d p}{d t}=\left(m_{d}-m_{s}\right) h_{g}
\end{aligned}
$$




$$
\begin{aligned}
& \text { where } M_{f} v_{f^{f}}+M_{g} v_{g}=v \\
& \text { and } \frac{d V}{d t}=-C_{12} \frac{d y}{d t}
\end{aligned}
$$

The total mass and internal energy of steam-water mixture in the steam drum are given by,

$$
\begin{aligned}
& M=M_{f}+M_{g} \\
& E=M_{f} h_{f}+M_{g} h_{g}-\frac{p V}{J}
\end{aligned}
$$

Combining Equations (B-3, B-5 and B-6), one can show that,

$$
E=M\left(h_{f}-\frac{v_{f}}{v_{f g}} h_{f g}\right)+v\left(\frac{h_{f g}}{v_{f g}}-\frac{p}{J}\right)
$$

The above expressions in parentheses are both functions of pressure only. Plotting these two expressions versus pressure, it can be easily shown that these expressions are both linear functions of pressure over the range of pressure variation involved in this analysis. Hence,

$$
E=M\left(C_{1}+C_{2} p^{*}\right)+V\left(c_{3}+C_{4} p^{*}\right)
$$

where $C_{1}, C_{2}, C_{3}$ and $C_{4}$ are constants. Introducing small perturbations around steady state for $E, M, V$ and $p$ and employing Equations (B-1, B-2 and B-8), the steam drum analog model, represented by Equations (7,8 and 9) can be developed.

\section{APPENDIX 3 - DETAILE OF FELDWATIER LINE ANALOG MODEL}

The feedwater line analog model is derived by the application cf momentum equation to. the feedwater flow through the feedpump, feedwater valve and interconnecting pipes. The momentum equation for the feedwater flow is given by,

$$
p_{1}-p=\frac{f_{c} \ell_{c}}{2 g \rho_{f} D_{c} A_{c}^{2}} m_{c}^{2}+\frac{1}{\rho_{f} A_{c}^{2}} f_{v} m_{c}^{2}
$$


In the above equation, the contribution of momentum change, being sufficiently small is.neglected. The pump discharge pressure $p_{1}$ is a given function of mass flow. rate and is obtained from the pump head-flow characteristic,

$$
p_{1}=H_{1}\left(n_{c}\right)
$$

The feedwater valve loss coefficient $f_{v}$ is given function of feedwater valve lift and is obtained from the valve specification,

$$
\mathbf{f}_{\mathbf{v}}=\mathrm{H}_{2}(\mathrm{~L})
$$

Introducing small perturbations around steady state for $m_{c}, p, p_{1}, f_{v}$ and $L$, expanding, Equations (C-2) and (C-3) in Taylor-Series about steady state point and neglecting. second and higher order terms, Equation (C-l) can be linearized. It can be easily shown that this linearization process gives,

$$
m_{c}^{*}\left[\left(\frac{d p_{1}}{d m_{c}}\right)_{0}-\frac{2\left(p_{1}-p\right)_{0}}{m_{c o}}\right]=p^{*}+L^{*} \quad\left(\frac{d f_{v}}{d L}\right) \cdot \frac{(/ p)_{0}}{f_{v o}}
$$

Rearranging Equation $(\mathrm{C}-4)$ and defining constants $\mathrm{C}_{5}$ and $\mathrm{C}_{6}$ results in Equation (10)。

APPENDIX, 4, - DETAILS OF STEAM MAIN TO TURBINE ÄNALOG MUDEL

The steam main analog model is derived by the application of momentum equation to the steam flow from steam generator discharge nozzle to turbine governor: valve.

$$
p-p_{n}=\frac{f_{s} \ell_{s}}{2 g \nu_{s} A_{s}^{2}} \quad v_{g} m_{s}^{2}
$$

In the development of the above equations, the steam discharge through the main is assumed to be $100 \% \mathrm{dry}$, therefore the contribution of momentum change may be neglected. Moreover, the steam main volume is lumped with steam generator drum volume. Consequently, the time-dependent term in the momentum equation can be 
1gnored. The friction factor, $f_{s}$, is a function of the Reynolds numbers. At the high Reynolds numbers involved in this problem, the variation of friction factor is insignificant. The saturated vapor specific volume $v_{g}$ is a function of main pressure. Since the steam main pressure is variable, it is assumed that. $v_{g}$ is calculated from steam tables on the basis of average main pressure,

$$
v_{g}=H_{3}(\bar{p}) \text { where } \bar{p}=\frac{p+p_{n}}{2}
$$

By introducing small perturbations around steady state for $p, p_{n}$, $v_{g}$ and $m_{s}$, expanding Equation (D-2) in Taylor-Series about steady state point and neglecting second and higher order terms, Equation $(D-1)$ can be linearized a.s follows:

$$
\left.p^{*}-p_{n}^{*}=\frac{f_{s} \ell_{g} m_{s o}^{2}}{2 g D_{B} A_{s}^{2}}\left[\frac{d v_{g}}{d \bar{p}}\right)_{0} \bar{p}+\frac{2 \cdot v_{g o}}{m_{s o}} \cdot m_{s}^{*}\right]
$$

Rearranging Equation $(D-3)$ and defining constants $C_{7}$ and $C_{8}$ results in Equation (5).

The turbine governor valve model is derived by assuming that critical flow conditions prevail at the valve opening at all times. : Consequently, the critical steam velocity at the valve opening is related to stagnation conditionsby the steady state energy equation,

$$
u_{c r}=\sqrt{2 g J\left(h_{g}-h_{c r}\right)}
$$

The critical enthalpy $h_{\mathrm{cr}}$ is found by maximizing, under isentropic conditions, the mas, velocity given by the following equation,

$$
G=\rho \sqrt{2 g J\left(h_{g}-h\right)}
$$

where $v$ and $h$ are functions of pressure at the valve opening. The steam flow rate through the turbine govcrnor valve is then given.by; 


$$
\begin{aligned}
m_{s} & =A_{m} \rho_{c r} \quad \sqrt{2 g J\left(h_{g}-h_{c r}\right)} \\
\text { where } \rho_{c r} & =H_{4}\left(p_{c r}\right) \\
\text { and } \quad p_{c r} & =c_{11} p_{n}
\end{aligned}
$$

Introducing small perturbations around steady state for $m_{s}, A_{m}$ and $\rho_{c r}$, expanding Equation (D-7) in Taylor-Serles about steady state and neglecting second and higher order terms, one obtains,

$$
m_{s}^{*}=\frac{m_{s o}}{A_{m o}} A_{m}^{*}+\frac{m_{s o}}{\rho_{\text {cro }}} \quad\left(\frac{d \rho_{c r}}{d p_{n}}\right)_{0} p_{n}^{*}
$$

Defining constants $C_{9}$ and $C_{10}$ results in Equation (12). 
Table I. Feedwater Valve Positioner Transfer Function and Characteristics

Feedwater Valve Lift Level Controller. Signal

$$
=\frac{k}{\left(\frac{s}{\omega_{n}}\right)^{2}+2 \zeta\left(\frac{s}{\omega_{n}}\right)+1}
$$

Time for Full Valve Stroke, Natural Frequency $\omega_{n}$, Seconds Radians/Seconds $n$ '

$$
\begin{array}{r}
2 \\
10 \\
20 \\
40
\end{array}
$$$$
2.0
$$$$
0.9
$$$$
0.63
$$$$
0.45
$$

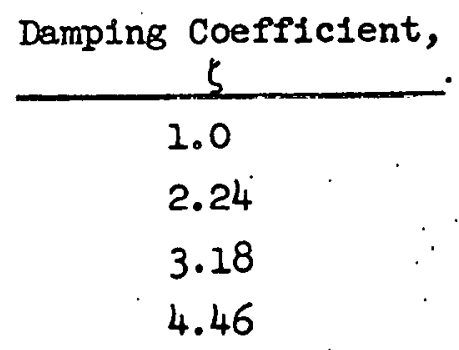

Table II. Steam Generator Parameters

Total thermal power (MWt)

Pressure (psia)

Steam flow (Ib/sec)

Recirculation ratio

Feedwater temperature $\left({ }^{\circ} \mathrm{F}\right)$

400

Table III. Values of Constants $C_{1}$ to $C_{12}$

$$
\begin{aligned}
& \mathrm{C}_{1}=470.15 \mathrm{Btm} / \mathrm{ib} \\
& \mathrm{C}_{2}:=\cdots 0.156 \mathrm{Btu} / \mathrm{lb} / \mathrm{psi} \\
& \mathrm{C}_{3}=1000.4 \mathrm{Btu} / \mathrm{ft}^{3} \\
& \mathrm{C}_{4}=1.224 \cdot \mathrm{Btu} / \mathrm{ft}^{3} / \mathrm{psi} \\
& C_{5}=4.703 \mathrm{Ib} / \mathrm{sec} \% \% \text { Iift } \\
& \mathrm{C}_{6}=-0.5265 \mathrm{Ib} / \mathrm{sec} / \mathrm{psi} \\
& \mathrm{C}_{7}=1.038 \\
& c_{8}=-0.1109 \mathrm{sec} / \mathrm{ft}^{2} \\
& c_{9}=0.7 \mathrm{ft}^{2} / \mathrm{sec} \\
& \mathrm{C}_{10}=\therefore 452.2 \mathrm{Ib} / \mathrm{sec} \\
& \mathrm{C}_{11}=0.58 \\
& c_{12}=43.5 \mathrm{ft}^{2}
\end{aligned}
$$



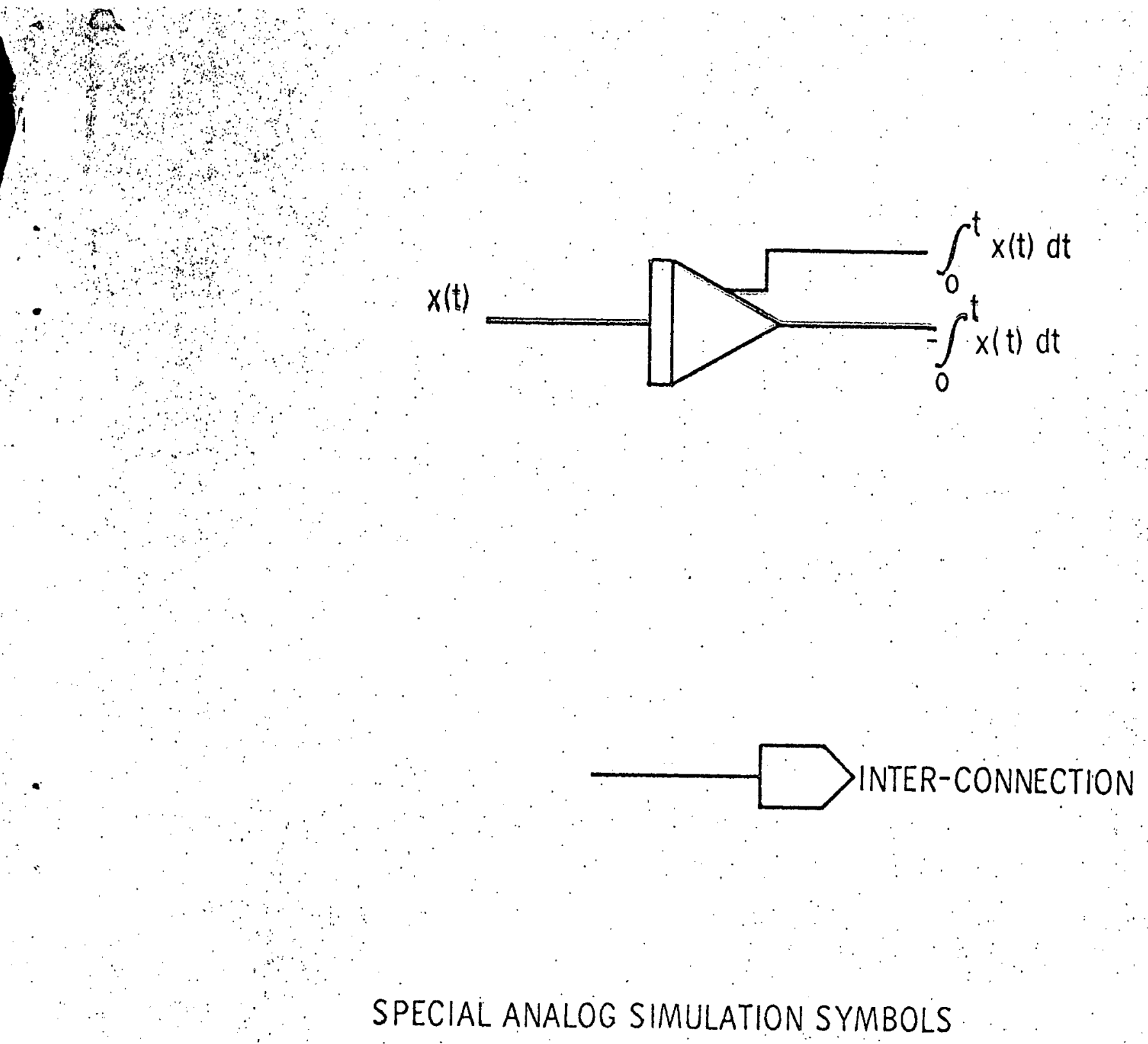

E. D. SK. 322397-B

FIGURE 18 